\title{
The role of mast cells in functional GI disorders
}

\author{
Mira M Wouters, ${ }^{1}$ Maria Vicario, ${ }^{2,3}$ Javier Santos ${ }^{2,3}$
}

${ }^{1}$ Translational Research Center for Gastrointestinal Disorders (TARGID), University Hospital Leuven, Leuven, Belgium

${ }^{2}$ Neuro-immuno-

gastroenterology Laboratory, Digestive Diseases Research Unit. Vall d'Hebron Institut de Recerca, Department of Gastroenterology, Hospital Universitari Vall d'Hebron \& Facultat de Medicina, Universitat Autònoma de Barcelona, Barcelona, Spain ${ }^{3}$ Centro de Investigación Biomédica en Red de Enfermedades Hepáticas y Digestivas (CIBERehd), Barcelona, Spain

\section{Correspondence to}

Dr Maria Vicario,

Laboratory of Neuro-Immuno-

Gastroenterology, Digestive

System Research Unit,

Department of

Gastroenterology, Vall d'Hebron Institut de Recerca \& Hospital Universitario Vall d'Hebron. Paseo Vall d'Hebron 119-129, Barcelona 08035 Spain; maria.vicario@vhir.org

Received 19 April 2015 Revised 27 June 2015 Accepted 30 June 2015 Published Online First 20 July 2015

CrossMark

To cite: Wouters MM, Vicario M, Santos J. Gut 2016;65:155-168.

\section{ABSTRACT}

Functional gastrointestinal disorders (FGIDs) are characterized by chronic complaints arising from disorganized brain-gut interactions leading to dysmotility and hypersensitivity. The two most prevalent FGIDs, affecting up to $16-26 \%$ of worldwide population, are functional dyspepsia and irritable bowel syndrome. Their etiopathogenic mechanisms remain unclear, however, recent observations reveal low-grade mucosal inflammation and immune activation, in association with impaired epithelial barrier function and aberrant neuronal sensitivity. These findings come to challenge the traditional view of FGIDs as pure functional disorders, and relate the origin to a tangible organic substrate. The mucosal inflammatory infiltrate is dominated by mast cells, eosinophils and intraepithelial lymphocytes in the intestine of FGIDs. It is well established that mast cell activation can generate epithelial and neuro-muscular dysfunction and promote visceral hypersensitivity and altered motility patterns in FGIDs, postoperative ileus, food allergy and inflammatory bowel disease. This review will discuss the role of mucosal mast cells in the gastrointestinal tract with a specific focus on recent advances in disease mechanisms and clinical management in irritable bowel syndrome and functional dyspepsia.

\section{INTRODUCTION}

Functional GI disorders (FGIDs) are characterised by chronic complaints arising from disorganised brain-gut interactions leading to dysmotility and hypersensitivity. FGIDs diagnosis is made by symptom-based approach using the corresponding Rome criteria. Functional dyspepsia (FD) and IBS are the two most prevalent FGIDs, affecting up to $16-26 \%$ of worldwide population. ${ }^{1}{ }^{2}$ However, despite these figures, their etiopathogenic mechanisms remain unclear, accounting for the lack of diagnostic biomarkers and the paucity of therapeutic options providing satisfactory long-standing clinical remission. $^{3}$

FGIDs are associated with a high prevalence of psychiatric comorbidities, chronic fatigue and chronic somatic and visceral pain disorders, rendering substantial social, humanistic and direct and indirect healthcare costs. ${ }^{4}$ Recent observations revealing the presence of low-grade mucosal inflammation and immune activation, in association with impaired epithelial barrier function ${ }^{5}$ and aberrant neuronal sensitivity, come to challenge the traditional view of FGIDs as pure functional disorders, and relate the origin to a tangible organic substrate that stimulates the search for innovative diagnostic and therapeutic approaches. Mast cells (MCs), eosinophils and intraepithelial lymphocytes dominate the inflammatory infiltrate in the intestine of FGIDs. MC activation can generate epithelial

\section{Key messages}

Mast cells play a central pathophysiological role in IBS and possibly in functional dyspepsia, although not well defined.

- Increased mast cell activation is a common finding in the mucosa of patients with functional $\mathrm{Gl}$ disorders.

- There is a need to implement standardised methods to count mast cells in the GI mucosa and to establish reference ranges of normality.

- Evaluation of spontaneous and stimulated mast cell function and activity on $\mathrm{Gl}$ samples is recommended when available.

- More studies are required to fully understand the implication of mast cells in the origin of clinical manifestations of these disorders.

- Treatment with mast cell stabilisers offers a reasonably safe and promising option for the management of those patients with IBS non-responding to conventional approaches, though future studies are warranted to evaluate efficacy and indications.

and neuromuscular dysfunction and promote visceral hypersensitivity and altered motility patterns in FGIDs, ${ }^{7-9}$ postoperative ileus, food allergy and IBD. ${ }^{10}$ This review will discuss the role of mucosal MCs in the GI tract with a specific focus on recent advances in disease mechanisms and management in IBS and FD.

\section{THE ORIGIN, PHENOTYPES AND FUNCTION OF GI MCS}

MCs are long-lived granulated cells derived from bone marrow myeloid-cell progenitors $\left(\mathrm{CD} 34^{+}\right)$, under the influence of stem cell factor and interleukin (IL)-4, cytokines that also regulate the development of MCs subtypes. ${ }^{11} \mathrm{MC}$ progenitor cells $\left(\mathrm{CD} 34^{+}, \mathrm{CD}^{+}{ }^{+}, \mathrm{c}-\mathrm{kit}^{+}, \mathrm{FccRI}^{-}\right)$circulate in low numbers in the blood and migrate to locate in close proximity to blood and lymphatic vessels, glands, smooth muscle and nerves. In the tissue, they remain as a homeostatic pool or they complete their differentiation process into mature MCs, as a direct consequence of genetic background, and inflammatory or bacterial-derived molecules released in the local microenvironment, including IL-3, IL-4, IL-9, IL-10, IL-33, CXCL12, transforming growth factor- $\beta$, nerve growth factor (NGF), and stem cell factor. ${ }^{12}$ Intestinal homing of MCs progenitor cells depends mostly on the binding of $\alpha 4 \beta 7$ integrin with their corresponding adhesion molecules such as cell adhesion molecule- 1 or vascular cell adhesion molecule- 1 on the endothelium, although the CXC 
chemokine receptor 2, expressed on MC progenitors, has been also implicated. ${ }^{13}$ Mature MCs are particularly abundant in body barriers, ready for optimal interaction with the local environment. In the GI tract, MCs comprise 1-5\% of mononuclear cells in the lamina propria and the submucosa, and are also found intraepithelial and deep in the muscle and serosal layers. Based on the anatomical location, human MCs are classified into mucosal MCs and connective tissue MCs, while depending on protease content, $\mathrm{MCs}$ are divided in two large subsets: $\mathrm{MC}_{\mathrm{T}}$, containing tryptase but little or no chymase, and $\mathrm{MC}_{\mathrm{TC}}$, containing tryptase, chymase and carboxypeptidase. ${ }^{12}{ }^{13} \mathrm{MC}_{\mathrm{C}}$, which express chymase but little or no tryptase, also have been described, but they appear to be infrequent. ${ }^{12}{ }^{13} \mathrm{MC}_{\mathrm{T}}$ prevail in the intestinal and pulmonary mucosa, near $\mathrm{T}$ cells, whereas $\mathrm{MC}_{\mathrm{TC}}$ are found in the skin and lymph nodes, in addition to the lung and the gut submucosa. ${ }^{11}$ In the human small intestine, $\mathrm{MC}_{\mathrm{T}}$ represent $\sim 98 \%$ of all MCs in the mucosa and $\sim 13 \%$ of MCs in the submucosa are $\mathrm{MC}_{\mathrm{T}}{ }^{12}$ Recently, a new phenotype of MCs expressing tryptase and carboxypeptidase A3, but not chymase, has been described in the airway epithelium in asthmatic subjects and in oesophageal samples of patients with eosinophilic esophagitis. ${ }^{14}$ Heterogeneity of MCs also includes differential content in heparin, cytokines and the receptor for the complement C5a, and the trans-differentiation between subtypes. $^{12} 13$ Therefore, location and granule content will determine the nature of mediators released to the extracellular milieu, accounting for modulation of specific functions in the GI tract. ${ }^{11}$

MCs have been viewed, for the most part, as effectors of allergy and anaphylaxis and are best known for their association with pathological conditions such as asthma. However, the advent of MC lines, mouse strains deficient in MCs and the reconstitution of these strains with bone marrow-derived MCs has greatly facilitated the characterisation of various aspects of MC function in vivo and their involvement in several disease states by interacting with a variety of other cells implicated in physiological and immunological responses. In the GI tract, MCs regulate vascular and epithelial permeability, ion secretion, angiogenesis, peristalsis, fibrosis and tissue repair, innate and adaptive immunity, bacterial defence, chemotaxis and nociception. ${ }^{11}$ Hence, uncontrolled or dysregulated MC activation may interfere with gut homeostasis and generate tissue dysfunction and promote inflammation in diverse GI diseases such as food allergy, IBD, postoperative ileus, autoimmune disorders, cancer and FGIDs. ${ }^{11}$ However, at the same time, MCs are indispensable for controlling a wide range of pathogenic infections, and for modulation innate and adaptive immune responses. ${ }^{15}$ Indeed, MCs can be intentionally activated to enhance protective host responses, including the production of high-affinity antibodies and immunological memory, raising the possibility of incorporating $\mathrm{MC}$ activators in vaccine formulations to harness the inherent adjuvant activity of MC activation. ${ }^{15}$

\section{REGULATION AND ACTIVATION OF MCS}

The classical and most effective stimulus for MC activation is cross-linking of cell surface-bound IgE to its high-affinity receptor (FceRI) by allergen in sensitised individuals. ${ }^{16}$ This results in a sequence of phosphorylation cascades and activation motifs that leads to intracellular calcium flux, activation of certain transcription factors such as AP-1 (c-FOS, v-Jun), MITF and STAT-5, and MC degranulation and cytokine production. ${ }^{17}$ MCs also express receptors for IgG ( $\mathrm{Fc} \gamma \mathrm{RI})$, immunoglobulin free-light chains (IgLC), other Ig-associated receptors, complement fractions and toll-like receptors. Moreover, MCs can be
Table 1 Triggers of mast cell activation

\begin{tabular}{|c|c|c|}
\hline $\begin{array}{l}\text { Type of } \\
\text { stimuli }\end{array}$ & $\begin{array}{l}\text { Type of } \\
\text { molecule }\end{array}$ & Molecule/stimuli \\
\hline \multirow[t]{2}{*}{ Immune } & Immunoglobulins & 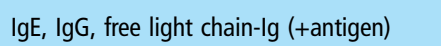 \\
\hline & Other & $\begin{array}{l}\text { C3a, C5a, IL-4, IL-6, IL-9, IL-10, TNF- } \alpha \text {, } \\
\text { IFN- } \gamma\end{array}$ \\
\hline \multirow[t]{6}{*}{ Non-immune } & Neurotransmitters & $\begin{array}{l}\text { Acetylcholine, dopamine, serotonin, } \\
\text { epinephrine, histamine }\end{array}$ \\
\hline & Neuropeptides & SP, VIP, HRP, CGRP, SS, NT, bradykinin \\
\hline & Hormones & ACTH, CRF, PTH, Ucn, oestradiol \\
\hline & Growth factors & NGF, SCF, TGF- $\beta$, FGF- 2 , VEGF, PD-ECGF \\
\hline & Biological & LPS, peptidoglycan, Mycobacterium \\
\hline & Physicochemical & $\begin{array}{l}\mathrm{NO} \text {, osmotic, thermal, } \mathrm{pH} \text {, humidity, } \\
\text { trauma, pressure, hypoxia, radiation, free } \\
\text { radicals }\end{array}$ \\
\hline \multicolumn{3}{|c|}{$\begin{array}{l}\text { Modified from ref.119 } \\
\text { ACTH, adrenocorticotropic hormone; C3a, complement component 3a; CGRP, calcitonin } \\
\text { gene-related peptide; CRF, corticotropin-releasing factor; FGF-2, fibroblast growth } \\
\text { factor-2; HRP, histamine-releasing peptide; IFN-y, interferon gamma; Ig, immunoglobulin; } \\
\text { IL, interleukin; LPS, lipopolysaccharide; NGF, nerve growth factor; NO, nitric oxide; NT, } \\
\text { neurotensin; VIP, vasoactive intestinal peptide; PD-ECGF, platelet-derived endothelial cell } \\
\text { growth factor; PTH, parathormone; SCF, stem cell factor; SP, substance P; SS, } \\
\text { somatostatin; TGF- } \beta \text {, transforming growth factor beta; TNF- } \alpha \text { : tumour necrosis factor } \\
\text { alpha; Ucn, urocortin; VEGF, vascular endothelial growth factor. }\end{array}$} \\
\hline
\end{tabular}

activated by neurotransmitters, neuropeptides, growth factors and hormones (table 1), accounting for MC versatility. Upon activation, MCs release newly synthesised (lipid mediators and cytokines) and stored (histamine, heparin, proteases) bioactive substances contained in cytoplasmic lipid bodies and granules (figure 1). Secretion is achieved by IgE-mediated rapid release of all granule contents by fusion of granules and extrusion (anaphylactic degranulation) or by partial or total granule emptying without inter-granule fusion (piecemeal degranulation). ${ }^{18}$ Neuropeptides, cytokines and microbial products induce piecemeal degranulation as frequently seen in diverse diseases, including IBD, IBS and FD. ${ }^{19}$

\section{FACTORS AND MECHANISMS UNDERLYING MC ACTIVATION IN THE GUT} Food antigens as trigger for MC activation

The majority of patients with FGIDs consider their symptoms to be related to meals. For example, $>60 \%$ of patients with IBS report the onset or worsening of symptoms after meals, within $15 \mathrm{~min}$ in $28 \%$ and within $3 \mathrm{~h}$ in $93 \%$ of these patients. ${ }^{20} 21$ Classically, in food allergy, MCs are activated by food antigendependent cross-linking of antigen-specific IgE to FceRI. Although some patients with IBS have a higher incidence of atopy, ${ }^{22}$ food allergy has not been convincingly associated to FGID pathogenesis. Of note, adverse reactions to food, including some types of food intolerance, may occur through IgG-mediated sensitisation of MCs, but the role for these IgG-mediated immune reactions remains to be established. ${ }^{20} 22$ When candidate food antigens are directly applied to the duodenal mucosa of IBS patients with suspected food intolerance through an endoscope, it caused immediate epithelial breaks, increased intervillous spaces and increased intraepithelial lymphocyte numbers in the intestinal mucosa, ${ }^{23}$ and an individualised exclusion diet improved symptoms in $74 \%$ of patients at 1-year follow-up. The underlying mechanism and the potential role for MCs requires further study. On the other hand, the response to food is also partly regulated by neuroendocrine factors including peripheral serotonergic responses. ${ }^{24}$ Although MCs can secrete and synthesise serotonin from tryptophan and serotonin is a chemotactic molecule for $\mathrm{MCs},{ }^{25}$ and 
Figure 1 Ultrastructure of human mucosal mast cell. (A) Ultrastructure of an activated mast cell in the intestinal mucosa, with irregular plasma membrane and numerous lipid bodies (arrow) and cytoplasmic granules, displaying piecemeal degranulation. Intact (white arrowhead) and degranulated (black arrowhead) granules are identified. (B and C) High-magnification micrographs of cytoplasmic granules from a mucosal mast cell. Different granule patterns are observed, with crystalloid structure (B) and scrolls (arrow, C). Enlarged empty and partially empty granule containers (black arrowhead) are typical of piecemeal degranulation. Bars: $1 \mu \mathrm{m}(\mathrm{A})$ and $0.5 \mu \mathrm{m}$ (B and $\mathrm{C})$.
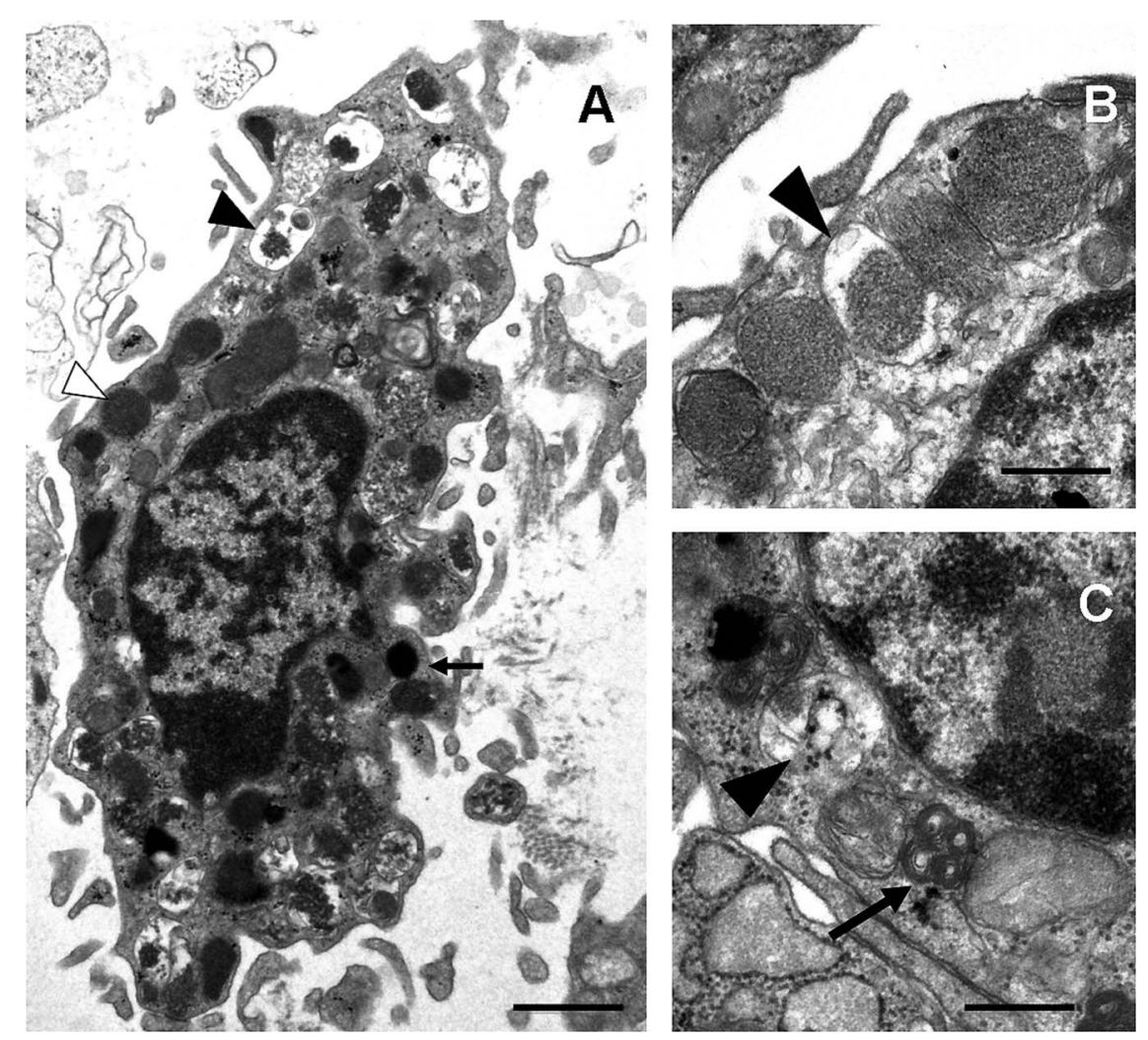

some adverse reactions to diet in FGIDs involve foods containing serotonin, including cheese, meat, soya beans, cereals, nuts and vegetables, ${ }^{26}$ the role of MCs in such responses, if any, is mostly ignored. Finally, spice intake correlates directly with the likelihood of developing IBS in females. ${ }^{27}$ Spicy foods contain capsaicin, the natural ligand of transient receptor potential vanilloid 1 (TRPV1) receptors on nociceptive afferent C-fibres. The increased density of sensory fibres expressing TRPV1 receptors reported in patients with FGIDs and visceral hypersensitivity, ${ }^{28}$ the genetic polymorphism of TRPV1 gene in $\mathrm{FD},{ }^{29}$ the potential TRPV1 sensitisation in patients with IBS, ${ }^{30}$ the close proximity of MCs to TRPV1 expressing sensory nerve fibres and the ability of capsaicin to modulate $\mathrm{MCs}^{31}$ all suggest that transmission of pain signals, including those generated by spicy foods, may be enhanced in FGIDs. In contrast, desensitisation of afferent terminals by a high capsaicin diet seems also plausible, as one study reported beneficial effects on abdominal bloating and pain in response to the ingestion of encapsulated red pepper for 6 weeks in IBS. ${ }^{32}$

\section{The role of infections}

Post-infectious (PI)-FGIDs represent common entities in daily clinical practice. Infectious gastroenteritis is associated with an increased risk for FD and IBS; however, the mechanisms leading to chronicity remain unknown. ${ }^{33}$ MCs are potential regulatory linkers between innate and adaptive immunity and have been demonstrated to play critical roles in host defence, participating in effective immune responses to a number of bacterial, parasitic, viral and fungal pathogen products. ${ }^{15}$ Antibody titres against bacterial flagellin are increased in patients with IBS and are even higher in PI-IBS. ${ }^{34}$ Recently, increased mucosal Ig production and upregulation of germline transcripts and Ig genes have been identified in diarrhoea predominant IBS (IBS-D) together with increased proximity between MC and plasma cell, suggesting MC activation by Ig. ${ }^{35}$ Whether FGID individuals may become sensitised to food and microbial antigens during an acute infection and subsequently develop antibodies that will activate MCs upon antigen exposure remains to be established.

\section{The role of stress}

Chronic stress may also lead to MC activation. In preclinical studies, several types of stresses and stress mediators such as corticotropin releasing hormone (CRF) and related peptides have been shown to modulate ion and water secretion as well as intestinal and colonic paracellular and transcellular permeability, primarily via nerve-MC interactions. ${ }^{36} 37$ Similarly, stress-induced rectal hyperalgesia could be prevented and reversed by administration of an MC stabiliser. ${ }^{38}$ Other studies have confirmed and extended this paradigm to the human intestine. Santos et al ${ }^{39}$ showed that a cold stress increased jejunal MC tryptase and histamine release along with intestinal water secretion, and intestinal permeability, with larger responses in women with moderate levels of background stress. ${ }^{40}$ CRF has been shown to enhance transcellular uptake of macromolecules in human colonic mucosa via CRF-R1 and CRF-R2 receptors located on subepithelial MCs. ${ }^{41}$ More recently, acute psychological stress (public speech) has been shown to increase small intestinal permeability in humans. ${ }^{42}$ This effect could be reproduced by peripheral administration of CRF, and blocked by the MC stabiliser disodium cromoglycate (DSCG). Preclinical models showed that chronic stress can induce substance $\mathrm{P}$ (SP) release by efferent nerves in the periphery, leading to CRF expression and release by intestinal eosinophils. Eosinophilderived CRF was then capable of activating MCs, resulting in jejunal epithelial barrier dysfunction. ${ }^{43}$ SP, NGF and sex steroids also induce the release of vasoactive mediators from MCs, contributing to chloride secretion, barrier dysfunction, hyperalgesia, diarrhoea, inflammation and motility changes. ${ }^{44} 45$

\section{INFILTRATION IN THE GI TRACT IN FGIDS}

Since the description by Weston et $a l^{46}$ in 1993 on the infiltration of the terminal ileum by MCs in IBS, numerous studies 
Table 2 Studies describing mast cell infiltration and activation in FD and IBS and potential correlation with symptoms

\begin{tabular}{|c|c|c|c|c|c|c|}
\hline Condition and number of subjects & Site of biopsy & Mast cell numbers & $\begin{array}{l}\text { Mast cell } \\
\text { detection }\end{array}$ & Mast cell mediators & Correlation with symptoms & Reference \\
\hline $141 \mathrm{FD}$ and 39 controls & Duodenum & Increased counts & $\begin{array}{l}\text { Toluidine blue } \\
\text { staining }\end{array}$ & NA & NA & 66 \\
\hline $15 \mathrm{FD}$ and 15 controls & Duodenum & Increased & Anti- tryptase & NA & NA & 9 \\
\hline 19 FD and 19 controls (paediatric) & & No change & Anti- tryptase & NA & No correlation between permeability and mast cell density & 120 \\
\hline 65 H. pylori-negative FD (paediatric) & $\begin{array}{l}\text { Gastric body and } \\
\text { duodenum }\end{array}$ & & Anti- tryptase & NA & $\begin{array}{l}\text { Headache was associated with high mast cell counts in the } \\
\text { gastric body and duodenum }\end{array}$ & 65 \\
\hline $\begin{array}{l}51 \text { FD, } 20 \text { IBS-D and } 21 \text { IBS-C and } 48 \\
\text { controls }\end{array}$ & Duodenum & $\begin{array}{l}\text { Increased counts in IBS-C and IBS-D } \\
\text { and trend for increase in FD }\end{array}$ & Anti-CD-117 & NA & NA & 61 \\
\hline $\begin{array}{l}62 \text { FD }(33 \mathrm{H} \text {. pylori-positive, } \\
29 \mathrm{H} \text {. pylori-negative and } \\
29 \mathrm{H} \text {. pylori-positive inflammatory } \\
\text { control subjects and } 20 \text { controls }\end{array}$ & Antrum and corpus & $\begin{array}{l}\text { Increased in } H \text {. pylori-negative and } \\
\text { positive FD samples in antrum and } \\
\text { corpus }\end{array}$ & Anti- tryptase & NA & NA & 64 \\
\hline 225 patients with non-ulcer dyspepsia & Antrum & $\begin{array}{l}31(13 \%) \text { were found to have } 11 \text { or } \\
\text { greater mast cells per high-power } \\
\text { field }\end{array}$ & $\begin{array}{l}\text { Alcian blue } \\
\text { staining }\end{array}$ & NA & NA & 121 \\
\hline $\begin{array}{l}\text { Total of } 101 \text { IBS and } 23 \text { controls, for } \\
\text { IHC: } 15 \text { controls; } 15 \text { IBS-C; } 14 \text { IBS-D }\end{array}$ & Descending colon & Increased counts & Anti-tryptase & NA & NA & 77 \\
\hline $\begin{array}{l}13 \text { IBS-D, } 8 \text { IBS-C and } 10 \text { controls } \\
\text { (paediatric) }\end{array}$ & $\begin{array}{l}\text { lleum, right colon and left } \\
\text { colon }\end{array}$ & $\begin{array}{l}\text { No change in numbers but mast } \\
\text { cells in closer proximity to nerves in } \\
\text { IBS (MC-NF/mm²) }\end{array}$ & Anti-tryptase & NA & $\begin{array}{l}\text { Abdominal pain correlated with } \mathrm{MC} / \mathrm{mm}^{2} \text { in the ileum and } \\
\mathrm{MC}-\mathrm{NF} / \mathrm{mm}^{2} \text { in the right colon }\end{array}$ & 122 \\
\hline 49 IBS-D and 30 controls & Jejunum & Increased counts in non-atopic IBS & Anti-CD-117 & NA & NA & 35 \\
\hline $100 \mathrm{IBS}$ and 100 controls & $\begin{array}{l}\text { Colon, ileum, duodenum } \\
\text { and stomach }\end{array}$ & No change & $\begin{array}{l}\text { Anti-CD-117 and } \\
\text { anti-CD-25 }\end{array}$ & NA & NA & 52 \\
\hline $\begin{array}{l}55 \text { IBS-D and } 18 \text { controls with lactase } \\
\text { deficiency }\end{array}$ & $\begin{array}{l}\text { Sigmoid colon, ascending } \\
\text { colon and terminal ileum }\end{array}$ & $\begin{array}{l}\text { Increased counts in the terminal } \\
\text { ileum, ascending and sigmoid colon }\end{array}$ & Anti-tryptase & NA & $\begin{array}{l}\text { Anxiety scores were associated with mast cell counts in } \\
\text { sigmoid colon, ascending colon and terminal ileum. } \\
\text { Visceral sensitivity (ie, decrease in urgency, discomfort/pain } \\
\text { threshold) was increased in patients with high mast cell } \\
\text { density in the terminal ileum }\end{array}$ & 123 \\
\hline 22 IBS-D and 21 controls & Rectum & Increased counts in IBS-D & Anti-tryptase & NA & $\begin{array}{l}\text { Mast cell counts did not correlate with IBS symptoms including } \\
\text { abdominal pain; mast cell counts correlated with substance P } \\
\text { and VIP in women but not in men }\end{array}$ & 124 \\
\hline $\begin{array}{l}83 \text { IBS-D, } 49 \text { UC ( } 28 \text { in remission and } 21 \\
\text { mildly active UC) and } 25 \text { controls }\end{array}$ & $\begin{array}{l}\text { Ascending, transverse, } \\
\text { descending, and sigmoid } \\
\text { colon }\end{array}$ & $\begin{array}{l}\text { Increased counts in patients with } \\
\text { IBS-D, UC in remission and mildly } \\
\text { active UC }\end{array}$ & Anti-tryptase & NA & NA & 125 \\
\hline $\begin{array}{l}51 \text { IBS, } 49 \text { quiescent IBD ( } 31 \text { CD and } 18 \\
\text { UC) and } 27 \text { controls }\end{array}$ & Caecum & $\begin{array}{l}\text { increased in patients with IBS, CD or } \\
\text { UC (no difference between patients } \\
\text { between patients with or without } \\
\text { IBS-like symptoms }\end{array}$ & Anti-CD-117 & NA & NA & 126 \\
\hline 16 IBS-D and 7 controls & Rectum & No change & Anti-tryptase & $\begin{array}{l}\text { Increased tryptase } \\
\text { release }\end{array}$ & Mast cell counts correlated with intestinal permeability & 127 \\
\hline 45 IBS-D and 30 controls & Jejunum & Increased counts & Anti-CD-117 & $\begin{array}{l}\text { Increased tryptase } \\
\text { mRNA and protein }\end{array}$ & $\begin{array}{l}\text { Tryptase mRNA expression but not mast cell counts correlated } \\
\text { with stool frequency and consistency in IBS-D patients; } \\
\text { tryptase protein expression correlated CLDN2 protein } \\
\text { overexpression and increased OCLN cytoplasmic staining }\end{array}$ & 8 \\
\hline 16 IBS-D, 21 IBS-C and 11 controls & Descending colon & $\begin{array}{l}\text { Increased counts in IBS-C but not } \\
\text { IBS-D }\end{array}$ & Anti-tryptase & NA & $\begin{array}{l}\text { Mast cell counts of IBS but not controls correlated with the } \\
\text { twitch enhancement evoked by biopsy supernatants }\end{array}$ & 87 \\
\hline
\end{tabular}




\begin{tabular}{|c|c|c|c|c|c|c|}
\hline Condition and number of subjects & Site of biopsy & Mast cell numbers & $\begin{array}{l}\text { Mast cell } \\
\text { detection }\end{array}$ & Mast cell mediators & Correlation with symptoms & Reference \\
\hline 34 IBS and 15 controls & Rectum & Increased counts & Anti-CD-117 & $\begin{array}{l}\text { Increased tryptase } \\
\text { release }\end{array}$ & $\begin{array}{l}\text { IBS severity correlated with colonic permeability, mast cell } \\
\text { counts and tryptase }\end{array}$ & 95 \\
\hline $\begin{array}{l}4 \text { IBS-C, } 11 \text { IBS-D, } 8 \text { IBS-A } \\
\text { and } 15 \text { controls }\end{array}$ & Colorectum & No change & Anti-tryptase & NA & NA & 128 \\
\hline 11 IBS-D and 14 controls (paediatric) & Rectum & No change & $\begin{array}{l}\text { Anti-tryptase and } \\
\text { anti-CD-117 }\end{array}$ & NA & NA & 129 \\
\hline $\begin{array}{l}15 \text { IBS-D, } 15 \text { IBS-C, } 36 \text { IBS-A } \\
\text { and } 20 \text { controls }\end{array}$ & Descending colon & decreased mast cell counts & Anti-CD-117 & NA & $\begin{array}{l}\text { No correlation between the number of mast cells and } \\
\text { abdominal pain or sensory thresholds of first sensation, urge } \\
\text { or discomfort }\end{array}$ & 51 \\
\hline 25 IBS-D and 23 controls & Jejunum & Increased counts & Anti-CD-117 & $\begin{array}{l}\text { Increased tryptase } \\
\text { mRNA }\end{array}$ & $\begin{array}{l}\text { Tryptase and SCF correlated with tight junction ZO protein } \\
\text { expression. Bowel frequency and stool consistency correlated } \\
\text { with both the number of mast cells and tryptase mRNA } \\
\text { expression, and with the expression of ZO proteins }\end{array}$ & 91 \\
\hline 12 IBS-C, 13 IBS-D and 12 controls & Descending colon & Increased counts & Anti-tryptase & $\begin{array}{l}\text { Increased serotonin, } \\
\text { histamine and tryptase } \\
\text { release irrespective of } \\
\text { bowel habit }\end{array}$ & $\begin{array}{l}5-\mathrm{HT} \text { release correlated with mast cell counts and the severity } \\
\text { of abdominal pain }\end{array}$ & 130 \\
\hline $60 \mathrm{IBS}$ and 22 controls & $\begin{array}{l}\text { Rectum and descending } \\
\text { colon }\end{array}$ & $\begin{array}{l}\text { decreased mast cell counts in rectal } \\
\text { biopsies }\end{array}$ & $\begin{array}{l}\text { Anti-tryptase and } \\
\text { anti-CD117 }\end{array}$ & $\begin{array}{l}\text { Lower release of } \\
\text { tryptase, slight increase } \\
\text { in histamine release }\end{array}$ & $\begin{array}{l}\text { The severity of abdominal pain was not correlated with mast } \\
\text { cell counts; no correlation between abdominal pain and } \\
\text { spontaneous histamine or tryptase release }\end{array}$ & 103 \\
\hline $\begin{array}{l}13 \text { IBS-D, } 8 \text { IBS-C, } 4 \text { IBS-A, } 10 \text { active CD } \\
\text { and } 18 \text { controls }\end{array}$ & Descending colon & $\begin{array}{l}\text { Increased counts in IBS-D but not in } \\
\text { IBS-C }\end{array}$ & Anti-CD-117 & $\begin{array}{l}\text { Increased trypsin-like } \\
\text { protein }\end{array}$ & NA & 131 \\
\hline $\begin{array}{l}27 \text { IBS-D, } 21 \text { IBS-C, } 12 \text { MC } 20 \text { UC and } \\
24 \text { controls }\end{array}$ & Descending colon & Increased counts & Anti-tryptase & NA & $\begin{array}{l}\text { Mast cell counts in patients with IBS was associated with } \\
\text { abdominal bloating frequency and with symptoms of } \\
\text { dysmotility-like dyspepsia, but not ulcer-like dyspepsia }\end{array}$ & 74 \\
\hline 7 IBS-D, 4 IBS-C and 4 controls & Descending colon & Increased counts & Anti-tryptase & $\begin{array}{l}\text { Increased tryptase and } \\
\text { histamine release but } \\
\text { not serotonin }\end{array}$ & $\begin{array}{l}\text { Association between the number of mast cells and the } \\
\text { corresponding supernatant-evoked spike frequency. Tryptase, } \\
\text { histamine and serotonin concentrations all correlated with the } \\
\text { supernatant-evoked action potential discharges }\end{array}$ & 80 \\
\hline $\begin{array}{l}8 \text { IBS-D, } 8 \text { IBS-C, } 7 \text { IBS-A and } 22 \\
\text { controls }\end{array}$ & Rectosigmoid & Increased counts & Anti-CD-117 & NA & c-kit ${ }^{+}$cells correlated with maximal VAS pain score & 28 \\
\hline $\begin{array}{l}50 \text { IBS, } 21 \text { controls, } 11 \text { depressed/ } \\
\text { fatigued patients without IBS }\end{array}$ & Caecum & $\begin{array}{l}\text { Increased in IBS, unchanged in } \\
\text { depressed/fatigued patients w/o IBS }\end{array}$ & Anti-CD-117 & NA & $\begin{array}{l}\text { In IBS, but not in controls or depressed patients, mast cell } \\
\text { counts correlated with the severity of fatigue and depression }\end{array}$ & 60 \\
\hline 29 IBS and 15 controls & Descending colon & Increased counts & Anti-tryptase & $\begin{array}{l}\text { Increased tryptase, } \\
\text { histamine and PGE2 } \\
\text { release }\end{array}$ & NA & 78 \\
\hline $\begin{array}{l}18 \text { IBS and } 12 \text { controls and } 4 \text { UC and } 1 \\
\text { CD }\end{array}$ & $\begin{array}{l}\text { Rectum and ascending } \\
\text { colon }\end{array}$ & No change & $\begin{array}{l}\text { Alcian blue } \\
\text { staining and } \\
\text { anti-tryptase }\end{array}$ & $\begin{array}{l}\text { Increased trypsin and } \\
\text { tryptase protein }\end{array}$ & NA & 79 \\
\hline 20 IBS-D and 14 controls & Jejunum & Increased counts & CD-117 & $\begin{array}{l}\text { Increased tryptase } \\
\text { release }\end{array}$ & $\begin{array}{l}\text { No correlation between mast cell counts and gender } \\
\text { or stress levels }\end{array}$ & 62 \\
\hline 20 IBS-D, 18 IBS-C and 20 controls & $\begin{array}{l}\text { Descending part of the } \\
\text { duodenum, proximal end } \\
\text { of jejunum and terminal } \\
\text { ileum }\end{array}$ & $\begin{array}{l}\text { Increased counts in IBS-C and IBS-D } \\
\text { in ileum but not duodenum or } \\
\text { jejunum }\end{array}$ & Anti-tryptase & $\begin{array}{l}\text { Decreased } 5-\mathrm{HT} \text { contents } \\
\text { at the jejunum in } \\
\text { patients with IBS-C }\end{array}$ & NA & 132 \\
\hline
\end{tabular}




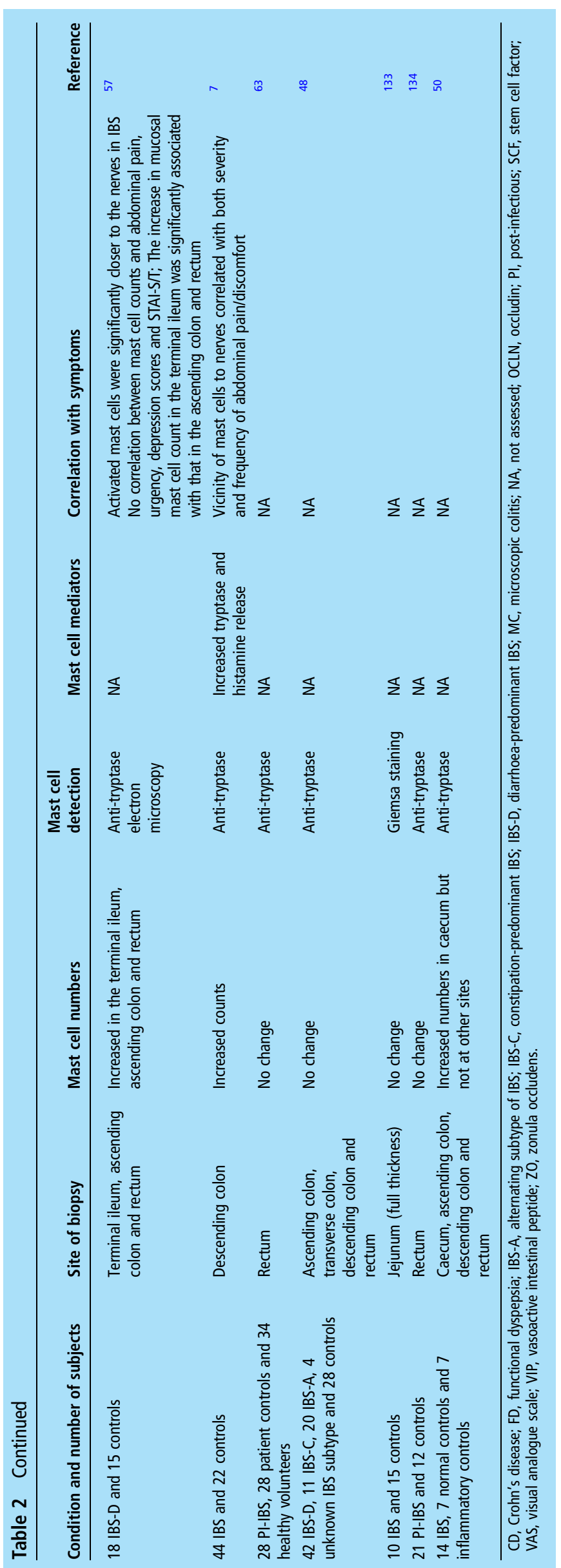

evaluated MC numbers in the GI mucosa of FGIDs (table 2). It is interesting to note here that the presence of low-grade intestinal inflammation in the gut of these patients also involves an increase in intraepithelial T lymphocytes, and less consistently, enterochromaffin cells, plasma cells, B lymphocytes, neutrophils and other immunocytes. 4748

MCs have been identified by metachromatic stains such as Giemsa or toluidine blue, but these methods have been replaced by immunohistochemistry (antibodies for c-kit (CD117) or tryptase $)^{49-51}$ because it is more sensitive and specific. MC counts are comparable with both stains, yet $\mathrm{CD} 117^{+}$cells display a more stable membranous staining, whereas tryptase ${ }^{+}$cells display cytoplasmic staining that could be influenced by cell degranulation. ${ }^{52}$ FGID biopsies contain singly dispersed MCs with no aggregates. ${ }^{52}$ When elevated MC counts are detected, it may be helpful to exclude systemic mastocytosis by staining for the low-affinity receptor for IL-2 (CD25). ${ }^{52}$ A reference range for significant increased MC counts is still lacking. This is partly due to the absence of agreement and standardisation on the methodology used to count MCs, to differences in patient and control selection, inter-individual variation, location of the biopsy, the relatively small cohort numbers for the majority of individual studies and to other uncontrolled potential confounding factors (box 1) (see Nasser et al for a detailed review). The great variation in reporting mean mucosal MC numbers in the GI tract makes the interpretation of discriminatory cut-off values very complicated and currently uninterpretable according to some pathologists. ${ }^{53} \mathrm{MC}$ counts have been found to be normal, increased or decreased in IBS (table 2). However, although the numbers vary across studies and segments, the analysis of $>1000$ IBS biopsies detects a mean, modest 1.2 -fold to 2.5 -fold increase in MC numbers throughout the entire GI tract. $^{5455}$ This is also true for cases of chronic undefined diarrhoea, mostly studied in the upper small bowel and left colon, to the point that some pathologists debate the convenience of coining the term mastocytic enterocolitis for this clinical-pathological association. ${ }^{56} \mathrm{~A}$ significant finding is that mucosal $\mathrm{MC}$ 'hyperplasia', when present, is not limited to the lower small intestine $^{57} 58$ and colon ${ }^{59}{ }^{60}$ but also involves the duodenum, ${ }^{61}$ the jejunum ${ }^{62}$ and the rectum. ${ }^{63}$ While there is discrepancy in IBS, available studies in FD reveal that MC numbers are significantly increased in the antrum and corpus of Helicobacter pylori-negative $\mathrm{FD},{ }^{64}{ }^{65}$ and in the duodenum of patients with FD (table 2). ${ }^{9} 616667$ Moreover, increased MCs have been recently reported in the oesophagus of patients suffering from

\section{Box 1 Conditions that may alter, commonly increase, the number of mast cell counts in the GI tract}

Allergic diseases: chronic urticaria, food allergy, atopy, hereditary angioedema. ${ }^{11} 98$

Mastocytosis and mast cell activation syndrome. ${ }^{52}$

Coeliac disease: increased in initial stages and decreased in later stages. ${ }^{135}$

Neuroendocrine cancer, lymphoma, epithelial cancers, carcinoid syndrome

H. pylori gastritis, infectious and parasitic enteritis,

IBS, ${ }^{136}$ lymphocytic colitis. ${ }^{48}$

Intestinal pseudo-obstruction, diverticulitis. ${ }^{137}$

Vasculitis, amiloidosis, drugs. 
non-cardiac chest pain. ${ }^{68}$ Even so, it is hard to dismiss the physiological relevance of such 'modest' increases because, on the one side, similar incremental changes in leucocyte counts in circulating blood occur in infectious and inflammatory conditions, and on the other side, the magnitude of cell change is enormous if we consider the total mucosal surface of the GI tract.

When evaluating MCs in IBS subtypes, some studies show that MC hyperplasia is more common in IBS-D 69 $^{70}$ and in non-PI $\mathrm{IBS}^{71}$ than in other subtypes, though in many other studies this is not the case. ${ }^{72-74}$ In contrast, MCs are increased similarly in gastric biopsies in PI-FD and non-specific FD. ${ }^{75}$ Moreover, others found MC numbers decreased in the descending colon of diarrhoea and alternating predominant IBS, but not constipation predominant IBS compared with health. ${ }^{51}$ There is also some indication that MC numbers remain increased compared with both non-PI IBS and controls, 3 years after Shigella infection. ${ }^{73}$ Although not the scope of this review, an increased number of MCs have been reported in the colorectal mucosa, in the lamina propria and in the submucosa from patients with Crohn's disease and UC. ${ }^{10}$

The role of gender differences in MC number is unclear. Several lines of evidence indicate that gonadal steroids are involved in gender-related differences in tissue MC infiltration in the colon. This difference in the number of MCs has been described in a variety of tissues from rodents, such as skin, myocardium and rat colon. When specifically analysed, some authors found increased MC counts in the terminal ileum, ascending and descending colon, and rectum of female versus male controls, ${ }^{576074}$ with females showing $43 \%$ increase in the area occupied by MCs, ${ }^{7}$ similar to observations in patients with chronic undefined diarrhoea, ${ }^{53}$ while others do not. ${ }^{51} 6063$ These data raise the hypothesis that gender-dependent differences in immune responses are involved in the observed higher prevalence of IBS in females, in the described gender-related differences in IBS pathophysiology and in the known effects of the menstrual cycle in the modulation of rectal sensitivity. ${ }^{76}$

Differences in MC numbers in the jejunum, caecum, colon or rectum of IBS are not attributable to age, stress and cortisol levels, anxiety or depression, or duration of the disease. ${ }^{51606269}$ Although disputed, it seems that changes in MC counts cannot be easily explained by differences in bowel preparation. $^{7} 48$ The role of diet on MC counts remains to be established. Thus, the diagnostic utility of routine MC stains in GI biopsies remains unclear and requires further investigation.

\section{ACTIVATION IN THE GI TRACT IN FGIDS}

MC activation in the GI tract may be evaluated by (1) morphological analysis, most commonly by checking ultrastructural characteristics of piecemeal or anaphylactic degranulation on transmission electron microscopy (TEM); (2) measuring the spontaneous or stimulated release of mediators in tissue, intestinal fluid and blood, most commonly tryptase and histamine, and less often hexosaminidase, carboxypeptidase A, heparin, chromogranin A, leukotriene E4, prostaglandin D2 and prostaglandin $9 \alpha, 11 \beta$ PGF2 and methylhistamine in urine; and (3) the expression of related genes and proteins in the mucosa (figure 2).

Based on TEM studies, it has been shown that MCs display higher activation rates in the caecum and rectum in IBS-D, and that activation rates increase even more when nerve-MC distance is $<2 \mu \mathrm{m} .{ }^{59}$ Moreover, MCs located within $5 \mu \mathrm{m}$ of nerve fibres were 3.1 times more frequent in the descending colon of IBS than in controls, and there was a $150 \%$ increase in the number of degranulating MCs. ${ }^{7}$ Furthermore, the ileal and colonic density of neuronal specific enolase, SP and 5hydroxytryptamine positively stained nerve fibres increased and appeared in clusters, surrounding an increased number of MCs with no differences between PI and non-post-infection patients with IBS. ${ }^{73} 77$

Supernatants of mucosal biopsies of patients with IBS contain increased concentrations of histamine, serotonin, trypsin, tryptase, prostaglandin E2, other proteases and cytokines. Moreover, jejunal luminal tryptase release was five times higher $^{62}$ and the expression of both tryptase mRNA and protein enhanced in jejunal tissue ${ }^{8}$ in IBS-D, while serum tryptase remained unaltered. Tryptase protein expression was also higher in both PI FD and non-specific FD gastric biopsies. ${ }^{64}$

It is interesting that $\lambda \operatorname{IgLC}^{+} \mathrm{MCs}$ but not $\operatorname{IgE}$ or $\operatorname{IgG}^{+} \mathrm{MCs}$ are reduced in the colon of IBS. ${ }^{51}$ This finding, together with the description of elevated serum concentrations of $\lambda$ and $\kappa$ IgFLC in IBS, ${ }^{81}$ suggests that Ig light chain-mediated MC activation may be associated with IBS.

Taken together, evidence indicates that the activity of MCs rather than an increased number is essential in the pathophysiology of FGIDs, a point that has been recently raised by several experts in the field.

\section{LINKING MC INFILTRATION AND ACTIVATION IN THE GI TRACT WITH CLINICAL MANIFESTATIONS IN FGIDS Role of MCs in visceral hypersensitivity and motility changes: motor and neuronal activation and sensitisation}

In the human gut, MCs lie in close proximity to GI mucosal sensory nerve fibres containing neuropeptides, including visceral afferents expressing TRPV1 receptors. ${ }^{82}$ This close spatial association, when coupled with MC activation, has been suggested to be of functional relevance for neuromuscular function and altered pain perception in response to insults such as infections, stress and emotions in FGIDs. ${ }^{47} 83$ Indeed, afferent innervation of enteric MCs can trigger the release of histamine and MC protease II, mediators that act in a paracrine manner to elevate the sensitivity of spinal afferent terminals. ${ }^{84}$ The use of supernatants obtained from biopsies allows us to study the effect of these mediators on neuronal activation and sensitisation. Injection of IBS-derived supernatants into rat mesenteric arteries evoked a marked increase in afferent nerve discharge, whereas injection of control supernatants had no effect. ${ }^{79}$ In addition, IBS-dependent excitation of dorsal root ganglia (DRG) was inhibited by histamine $\mathrm{H} 1$ receptor blockade and serine protease inactivation, ${ }^{78}$ underscoring the role of $\mathrm{MC}$ mediators in neuronal activation. These findings were confirmed by Buhner et al, who reported that IBS biopsy supernatants, but not those of healthy controls, significantly increased the spike discharge of human submucosal neurons. This effect was inhibited by histamine receptor $(\mathrm{H} 1-\mathrm{H} 3)$ antagonists, 5-HT3 receptor antagonist and protease inhibition. ${ }^{80}$ Moreover, supernatants from hypersensitive patients with IBS caused stronger activation of guinea pig enteric and mouse DRG neurons compared with supernatants of normosensitive patients, ${ }^{85}$ indicating that neuronal activation responses in vitro correlate with the individual pain threshold pressure values. Others showed that intracolonic infusion of IBS supernatants, but not controls, caused increased nociception in response to colorectal distention in mice, an effect that could be prevented by a serine protease inhibitor and was absent in neurons lacking functional protease-activated receptor-2. ${ }^{79}$ More recently, Cenac et $a l^{86}$ showed that colonic biopsies from patients with IBS contain increased levels of polyunsaturated fatty acid (PUFA) metabolites, these are endogenous TRPV4 agonists, compared with healthy subjects, and these 


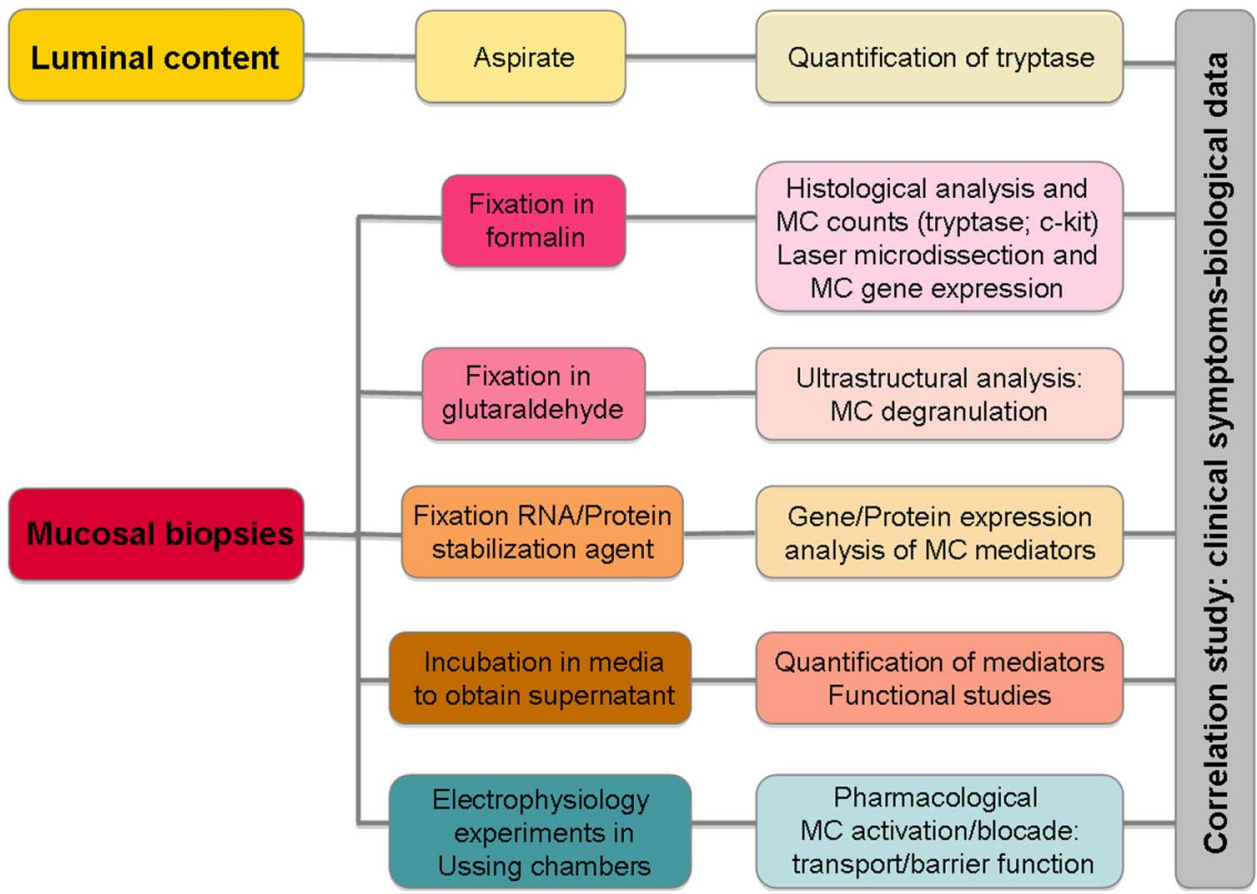

Figure 2 Schematic representation of the experimental procedure to assess mucosal mast cell activation. Mast cell activation can be measured in intestinal samples. Luminal content can be obtained by aspiration, before biopsies are collected, and tryptase content can be quantified. Different mucosal biopsies can be processed for histological examination, including mast cell counting after immunohistochemistry (tryptase and/or c-kit staining) and laser microdissection for ulterior gene expression analysis; ultrastructure analysis, to assess the type and degree of degranulation and to identify granule pattern; gene expression analysis of specific mediators synthesised and released by mast cells (tryptase, carboxypeptidase, chymase); quantification of mediators that are spontaneously released from biopsies and/or performing functional studies in vitro (muscle/nervous cells) or in vivo (mice/rats); and electrophysiology experiments in Ussing chambers for identification of mast cell-dependent changes in barrier function. Finally, analysis of the possible association between clinical manifestations and mast cell activation can be performed.

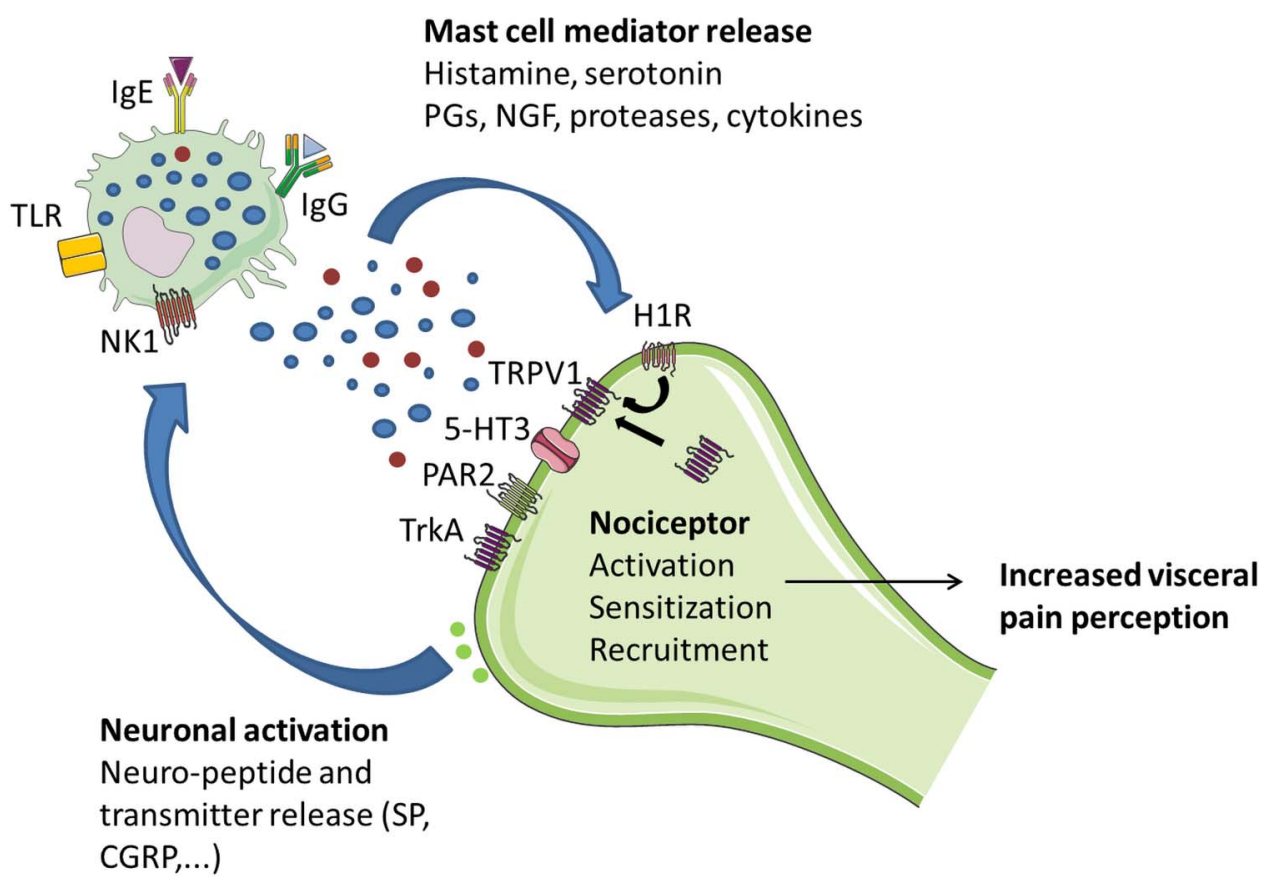

Figure 3 Schematic illustration of mast cell-nerve interactions in human gut. MCs and nerves communicate bidirectionally, thereby modulating peristalsis and pain signalling. The release of bioactive, pro-inflammatory, mediators by mast cells results in a variety of neuronal effects including activation, sensitisation and recruitment of nociceptors to the cell membrane, neurogenic inflammation and neural sprouting, ultimately leading to visceral hypersensitivity. On the other hand, neuronal activation triggers the release of neuropeptides and neurotransmitters, thereby further activating mast cells. 5-HT3, 5-hydroxytryptamine receptor 3; CRGP, calcitonin-related gene peptide; H1R, histamine receptor 1; Ig, immunoglobulins; NK1, neurokinin 1 receptor; NGF, neuronal growth factor; PGs, prostaglandins; PAR2, proteinase-activated receptor-2; SP, substance P; TRPV1, transient receptor potential vanilloid 1; TLR, toll-like receptor; TrkA, receptor for nerve growth factor. 
increases correlated with pain and bloating scores. PUFA metabolites extracted from IBS biopsies or colons of mice with visceral hypersensitivity activated mouse sensory neurons in vitro, by activating TRPV4, an effect that could be prevented by siRNA knockdown of TRPV4. ${ }^{86}$ Finally, application of supernatants on muscle strips evoked excitatory cholinergic longitudinal muscle contractions of the guinea pig ileum, an effect that was not dependent on serotonin, proteases or histamine but was (partially) mediated by TRPV1, purinergic P2X receptors and prostanoid receptors. ${ }^{87}$ Ballestra et al speculate that afferent nerve activation may induce myenteric cholinergic depolarisations, leading to altered motor function (figure 3).

Besides increased neuronal activation, supernatant of biopsies from patients with IBS also has the capacity to potentiate sensory nerves. In a recent, elegant study, murine DRG neurons were incubated overnight with supernatants of submucosal colonic biopsies of IBS. Patch clamp recordings the next day revealed that the intrinsic excitability of the colonic nociceptive DRG neurons was increased by IBS-D supernatants. This increased excitability was not observed in DRG neurons lacking PAR-2. ${ }^{88}$ Finally, incubation of a neuronal cell line or rat primary myenteric neuron cultures with mucosal biopsy supernatants from IBS also induced long-lasting neuroplastic changes as reflected by increased NGF-dependent neuronal sprouting. ${ }^{77}$

Together, these preclinical data consistently indicate that the mucosa and submucosa of patients with IBS contains increased levels of various MC mediators that have the potential to activate and potentiate intrinsic and afferent neurons, thereby leading to increased visceral pain perception and altered motor function that may cause diarrhoea or constipation as a result of excessive segmental contractile colonic motor activity (table 3 ). Of note, the use of human supernatants on animal models or isolated neurons may not completely reflect human physiology as MCs and enteric neurons exhibit species specificity in mediator release mechanisms and receptor profile. ${ }^{16}$ To further assess the functional relevance and specificity of supernatant-mediated activation of nerve endings in the gut, it may be of great interest to perform live imaging of $\mathrm{MC}$-nerve signalling in human preparations or to perform confocal endomicroscopy. The latter has recently been used to identify suspected food intolerance in patients with IBS. ${ }^{23}$
Role of MCs in the regulation of intestinal barrier function: secretion and permeability

MCs' contribution to barrier function was first described in animal studies in which increased ion secretion and transepithelial transport of macromolecules was reversed with an MC stabiliser. $^{89}$ In humans, stress induces the release of MC mediators (tryptase, histamine) to the intestinal lumen ${ }^{39}$ and increases intestinal permeability, which can be reversed by oral DSCG. ${ }^{42}$ Stress can severely impact on barrier function and favour intestinal disease, as might be the case for FGIDs. IBS and FD patients experience high levels of anxiety, depression and stress ${ }^{3}$ and intestinal permeability, as measured by probe excretion assays, has been found altered, primarily in PI-IBS and IBS-D. ${ }^{90}$ The mechanisms underlying epithelial barrier alterations are not fully understood, but disruption of the proteins that seal the paracellular space seems to play a role. Actually, in IBS, the expression of several tight junctions (TJ) proteins is reduced compared to controls and, in IBS-D, this reduction correlates with MC activation and with common clinical symptoms. ${ }^{91}$ In FD, the altered expression of cell-to-cell adhesion proteins also correlates with impaired duodenal integrity and with mucosal inflammation. ${ }^{9}$ MCs' proximity to the epithelium facilitates tryptase activation of PAR-2 receptors on the basolateral side of enterocytes, leading to redistribution of TJ and increased paracellular permeability to macromolecules. ${ }^{92}$ Other mediators released by MCs upon activation, such as histamine, chymase and prostaglandin D2, regulate epithelial chloride and water secretion and permeability. ${ }^{93} 94$ MC-mediated intestinal barrier alterations have been also related to neuropeptides, neurotransmitters, hormones (vasoactive intestinal peptide, SP, NGF, oestrogen, oestradiol), and inflammatory mediators (tumour necrosis factor- $\alpha$, interferon- $\gamma$ and cytokines) released by other immunocytes $^{93}$ (figure 4).

\section{Role of MCs in IBS cardinal manifestations}

MCs in close proximity to nerves in the descending colon were significantly correlated with severity and frequency of abdominal pain/discomfort. ${ }^{7}$ In another study, mucosal MC infiltration was significantly associated with abdominal bloating frequency and with symptoms of dysmotility-like dyspepsia. ${ }^{74}$ In contrast, in IBS, there was no correlation between severity or frequency of abdominal pain/discomfort and lamina propria area occupied

Table 3 Effect of mast cell mediators on GI function

\begin{tabular}{|c|c|c|c|c|}
\hline Mediator & Receptor & IBS/cell type & Effect & Reference \\
\hline \multirow[t]{4}{*}{ Histamine } & H1R & IBS-C; IBS-D & Excite rat mesenteric afferents & 78 \\
\hline & & & Excite murine DRG neurons & 78 \\
\hline & $\mathrm{H} 1-\mathrm{H} 3 \mathrm{R}$ & IBS-C; IBS-D & Excite human submucosal neurons & 80 \\
\hline & - & - & Epithelial secretion of $\mathrm{Cl}^{-}$and $\mathrm{H}_{2} \mathrm{O}$ & 138 \\
\hline \multirow[t]{4}{*}{ Tryptase } & PAR2 & IBS-C; IBS-D & Sensitise/activate murine DRG neurons & 78 \\
\hline & & IBS-C; IBS-D & Excite human submucosal neurons & 80 \\
\hline & & $\begin{array}{l}\text { IBS-D but not } \\
\text { IBS-C }\end{array}$ & Sensitisation murine colonic DRG neurons & 88 \\
\hline & & IBS-D, IBS-A & Increase epithelial permeability & 139 \\
\hline \multirow[t]{2}{*}{ Serotonin } & $5 \mathrm{HT} 3 \mathrm{R}$ & IBS-C; IBS-D & Excite human submucosal neurons & 80 \\
\hline & & T84 cells & Secretory response & 140 \\
\hline \multirow[t]{2}{*}{ PGD2 } & DP1 & IBS-C and IBS-D & Excite guinea pig longitudinal muscle strips & 87 \\
\hline & - & - & Epithelial secretion of $\mathrm{Cl}^{-}$and $\mathrm{H}_{2} \mathrm{O}$ & 138 \\
\hline Chymase & PAR2 & Caco BBe & Increase epithelial permeability & 94 \\
\hline
\end{tabular}




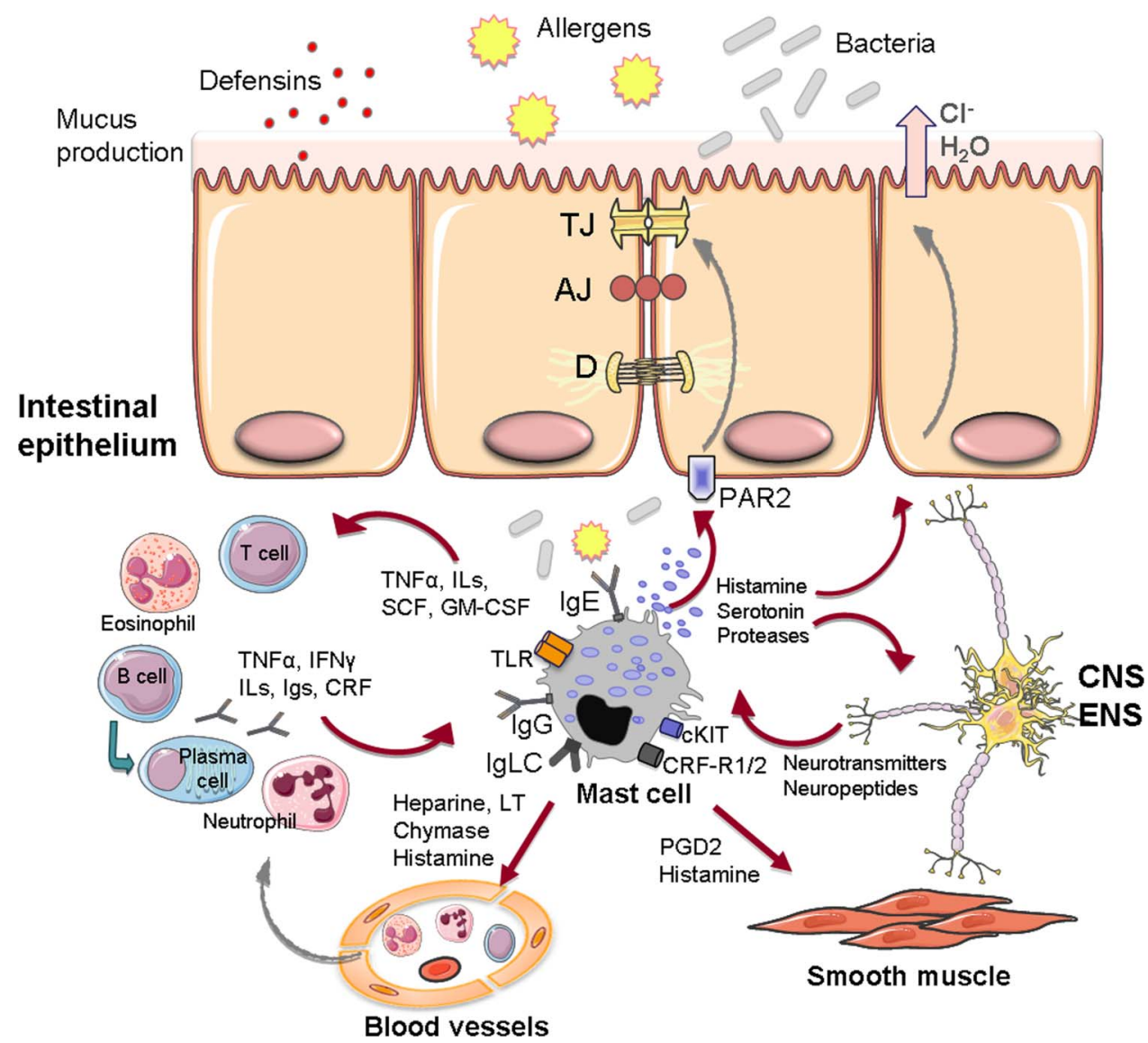

Figure 4 Intestinal barrier function elements and mast cell interactions in the intestinal mucosa. Illustration of the potential mast cell interactions in the regulation of barrier function, including epithelial permeability (through TJ modulation and secretory response), recruitment and activation of other immunocytes, endothelial functions (vascular permeability and blood flow), peristalsis and pain signalling through bidirectional communication with the nervous system. $5 \mathrm{HT}_{3} \mathrm{R}$, 5-hydroxytryptamine receptor; $\mathrm{AJ}$, adherens junction; CRFR1/2, CRF receptors 1 and 2; CNS, central nervous system; CRF, corticotropin-releasing factor; D, desmosome; ENS, enteric nervous system; GM-CSF, granulocyte and monocyte colony stimulating factor; IFN- $\gamma$, interferon gamma; Igs, immunoglobulins; IgE, Immunoglobulin E; IgG, Immunoglobulin G; IgLC, immunoglobulin free-light chains; ILs, interleukins; LT, leukotrienes; PAR2, proteinase-activated receptor-2; PGD2, prostaglandin D-2; SCF, stem cell factor; TNF- $\alpha$, tumour necrosis factor alpha; TLR, toll-like receptor; TJ, tight junction.

by MCs, release of tryptase and histamine, and number of degranulated MCs per field. ${ }^{7} 57$ IBS-D patients with rectal hypersensitivity, according to the maximally tolerable pressure to barostat distention, showed significantly lower counts of MCs in the terminal ileum, ascending colon and rectum in one study. ${ }^{57}$ Park et $a l^{57}$ speculated that this counterintuitive finding was related to tissue desensitisation by MC mediators. More recently, Braak et $a l^{51}$ found no correlation between the sensory thresholds to barostat distention, abdominal pain, bloating, urgency, incomplete evacuation, hard stools, loose stools, frequent and decreased bowel moments and flatulence and MC counts in the colon. An association between duodenal and antral MCs with pain, and postprandial distress syndrome, respectively, has been shown in children with FD. ${ }^{67}$

Impaired intestinal permeability, and the expression of TJ proteins, has been shown to correlate with pain/discomfort and/ or bowel habit. ${ }^{90} 919596$ Interestingly, tryptase mRNA and protein expression in the jejunum of patients with IBS-D correlated with stool frequency and consistency but not with abdominal pain, whereas the correlation with $\mathrm{MC}$ number was poor. ${ }^{91}$

Caecum MC counts correlated significantly with the fatigue and depression scores in IBS, ${ }^{60}$ and in some studies, there is a tendency or an association between depression and state of anxiety scores and the number of MCs in patients with IBS-D. ${ }^{57}$
A significant correlation with antral MC densities with anxiety, depression and somatisation has been reported in children with FD. ${ }^{67}$ Moreover, the degranulation of MCs in the duodenum appears to be highly sensitive and specific for the identification of adult patients with FD as shown by $100 \%$ sensitivity and specificity indicated by an area under the receiver operating characteristic curve of 1.0 for the optimal degranulation rate cut-off values of $30.2 \%$ at the duodenal bulb and $36.8 \%$ at the descending part of the duodenum. ${ }^{66}$

Taken together, these findings suggest that interactions between the MCs and the enteric and brain-gut neural networks could be of importance in symptom perception in at least a subgroup of patients with FGIDs.

\section{TARGETING MCS: IMPLICATIONS FOR TREATMENT OF FGIDS}

The MC stabiliser DSCG abolished the effect of acute psychological stress on small bowel permeability in human subjects. ${ }^{42}$ Aside from experimental studies demonstrating the efficacy of several MC inhibitors to decrease colonic hypersensitivity, in humans, a number of uncontrolled observations, ${ }^{56}$ and open clinical studies with DSCG, in doses between 600 and $1800 \mathrm{~g} /$ day, suggest its clinical benefit for chronic persistent diarrhoea, ${ }^{97}$ allergic enteritis, ${ }^{98}$ FD $^{99}$ and IBS. ${ }^{100-102}$ However, these studies had 
several limitations, including poor design, small sample size and selection bias. Likewise, ketotifen has been recently proven to increase the sensory threshold, leading to improved visceral perception, especially in the hypersensitivity IBS group. ${ }^{103}$ Although preliminary, there is some indication of the clinical benefit of ketotifen and the tryptase inhibitor APC 2059 in UC. ${ }^{104} 105$ Our group has recently finished an open trial (awaiting publication) and a consecutive double-blind, placebo-controlled, clinical assay, with prolonged (6 months) oral administration of DSCG, with promising results in the control of main clinical manifestations in patients with IBS-D (Gastroenterology 2015;148(Suppl 1): S-494) ${ }^{106}$ In addition, small studies have shown improvement in GI symptoms with DSCG therapy in systemic mastocytosis. ${ }^{107}$ However, the mechanisms by which MC stabilisation could interfere with IBS clinical response have not been clearly delineated.

Other interventions that block the effects of MC mediators and improve GI symptoms should be considered. In this sense, antiinflammatory treatment with mesalazine appeared to show improvement in symptom perception in unselected patients with IBS in a small proof-of-concept randomised, double-blind, placebo-controlled trial, in which, in addition, a 36\% decrease in MC numbers and a reduction of the number of total immune cells and $\mathrm{T}$ cells was observed in the colonic mucosa. ${ }^{108}$ However, two subsequent large clinical trials differ in the clinical benefit of mesalazine in IBS, ${ }^{109} 110$ and the effect of mesalazine on MC counts and degranulation was not confirmed. ${ }^{110}$ Furthermore, there was no effect of mesalazine on 5-HT containing enterochromaffin and CD68 cell numbers, although there was a significant increase in CD3 count in the mesalazine group. ${ }^{110}$ In further reinforcing the role of MC activation in the origin of FGID manifestations, it is important to note that heartburn, cramping, nausea, abdominal pain and diarrhoea are the second most common complaint of patients with mastocytosis, and that H2-histamine receptor antagonists have been quite effective in controlling these symptoms. ${ }^{56} 98111$ A recent proof-of-principle clinical trial confirmed the clinical relevance of these findings showing improvement of abdominal pain and global relief by the H1R antagonist ebastin in patients with IBS (Gastroenterology 2013;144(Suppl 1):S-160). ${ }^{112}$ Palmitoylethanolamide and other inhibitors of cannabinoid receptors seem efficacious in controlling pain, motor disturbances and inflammation in animal models through modulation of neuronal and non-neuronal cells, including MCs ${ }^{113}{ }^{114}$ Slow release of vitamin $\mathrm{C}$ may be also helpful as it increases degradation of histamine and inhibits MC degranulation in doses not superior to $750 \mathrm{mg} /$ day. ${ }^{111}$ Natural flavonoids (fisetin, kaempferol, quercetin, rutin, luteolin) and the active alkaloid berberine inhibit the mediator release of MCs in vitro ${ }^{115}$ and protect intestinal epithelial barrier. ${ }^{114}$ While some of these products have been shown to be useful in cardiovascular health ${ }^{117}$ and cancer, ${ }^{118}$ their clinical efficacy in FGIDs has not been established. There is some evidence of symptomatic response to specific diets in FGIDs, such as low FODMAP and gluten-depleted food. ${ }^{20}$ However, there is no support for the role of MCs in this symptomatic response with the exception of the benefit after individualised exclusion of foods in FGIDs suffering food allergy.

Finally, the development of more specific and safe blockers or modulators of IgE, IgG or other activation pathways of MC activation, including pathways involved in the selective release of mediators, may offer therapeutic advantages, although their benefit remains to be established.

\section{CONCLUSION}

Current evidence implicating MCs in the pathogenesis and pathophysiology of FGIDs, particularly in IBS, and the contribution of their activation and released mediators to the development of cardinal manifestations, such as epigastric and abdominal pain, and altered defecation is robust, and supports the targeting of MCs in the management in FGIDs.

Funding Supported in part by Fondo de Investigación Sanitaria and CIBERehd, Instituto de Salud Carlos III, Subdirección General de Investigación Sanitaria, Ministerio de Economía y Competitividad: CP10/00502 \& PI13/00935 (MV); PI11/00716 \& PI14/00944 (JS); Centro de Investigación Biomédica en Red de Enfermedades Hepáticas y Digestivas: CB06/04/0021 (MV and JS), and MMW is supported by a FWO postdoctoral fellowship (1248513N).

Competing interests None declared.

Provenance and peer review Commissioned; externally peer reviewed.

\section{REFERENCES}

1 Lovell RM, Ford AC. Global prevalence of and risk factors for irritable bowel syndrome: a meta-analysis. Clin Gastroenterol Hepatol 2012;10:712-21.

2 Tack J, Talley NJ. Functional dyspepsia-symptoms, definitions and validity of the Rome III criteria. Nat Rev Gastroenterol Hepatol 2013;10:134-41.

3 Spiegel B, Camilleri M, Bolus R, et al. Psychometric evaluation of patient-reported outcomes in irritable bowel syndrome randomized controlled trials: a Rome Foundation report. Gastroenterology 2009;137:1944-53.

4 Nellesen D, Yee K, Chawla A, et al. A systematic review of the economic and humanistic burden of illness in irritable bowel syndrome and chronic constipation. J Manag Care Pharm 2013;19:755-64.

5 Matricon J, Meleine M, Gelot A, et al. Associations between immune activation, intestinal permeability and the irritable bowel syndrome. Aliment Pharmacol Ther 2012;36:1009-31.

6 Nasser Y, Boeckxstaens GE, Wouters MM, et al. Using human intestinal biopsies to study the pathogenesis of irritable bowel syndrome. Neurogastroenterol Motil 2014;26:455-69.

7 Barbara G, Stanghellini V, De Giorgio R, et al. Activated mast cells in proximity to colonic nerves correlate with abdominal pain in irritable bowel syndrome. Gastroenterology 2004;126:693-702.

8 Martínez C, Lobo B, Pigrau M, et al. Diarrhoea-predominant irritable bowel syndrome: an organic disorder with structural abnormalities in the jejunal epithelial barrier. Gut 2013;62:1160-8.

9 Vanheel H, Vicario M, Vanuytsel T, et al. Impaired duodenal mucosal integrity and low-grade inflammation in functional dyspepsia. Gut 2014;63:262-71.

10 De Winter BY, van den Wijngaard RM, de Jonge WJ. Intestinal mast cells in gut inflammation and motility disturbances. Biochim Biophys Acta 2012;1822:66-73.

11 Bischoff SC. Role of mast cells in allergic and non-allergic immune responses: comparison of human and murine data. Nat Rev Immunol 2007;7:93-104.

12 Reber LL, Sibilano R, Mukai K, et al. Potential effector and immunoregulatory functions of mast cells in mucosal immunity. Mucosal Immunol 2015;8:444-63.

13 da Silva EZ, Jamur MC, Oliver C. Mast cell function: a new vision of an old cell. J Histochem Cytochem 2014;62:698-738.

14 Dougherty RH, Sidhu SS, Raman K, et al. Accumulation of intraepithelial mast cells with a unique protease phenotype in $\mathrm{T}(\mathrm{H}) 2$-high asthma. J Allergy Clin Immunol 2010;125:1046-1053.e8.

15 Abraham SN, St John AL. Mast cell-orchestrated immunity to pathogens. Nat Rev Immunol 2010;10:440-52.

16 Galli SJ, Grimbaldeston M, Tsai M. Immunomodulatory mast cells: negative, as well as positive, regulators of immunity. Nat Rev Immunol 2008;8:478-86.

17 Rivera J, Gilfillan AM. Molecular regulation of mast cell activation. J Allergy Clin Immunol 2006;117:1214-25.

18 Dvorak AM. Ultrastructural studies of human basophils and mast cells. J Histochem Cytochem 2005;53:1043-70.

19 Crivellato E, Nico B, Mallardi F, et al. Piecemeal degranulation as a general secretory mechanism? Anat Rec A Discov Mol Cell Evol Biol 2003;274:778-84.

20 Gibson PR, Varney J, Malakar $S$, et al. Food components and irritable bowel syndrome. Gastroenterology 2015;148:1158-74.

21 Simren M, Månsson A, Langkilde AM, et al. Food-related gastrointestinal symptoms in the irritable bowel syndrome. Digestion 2001;63:108-15.

22 Cuomo R, Andreozzi P, Zito FP, et al. Irritable bowel syndrome and food interaction. World I Gastroenterol 2014;20:8837-45.

23 Fritscher-Ravens A, Schuppan D, Ellrichmann M, et al. Confocal endomicroscopy shows food-associated changes in the intestinal mucosa of patients with irritable bowel syndrome. Gastroenterology 2014;147:1012-20.

24 Sengupta $P$. The belly rules the nose: feeding state-dependent modulation of peripheral chemosensory responses. Curr Opin Neurobiol 2013;23:68-75.

25 Ferjan I, Lipnik-Štangelj M. Chronic pain treatment: the influence of tricyclic antidepressants on serotonin release and uptake in mast cells. Mediators Inflamm 2013;2013:340473. 
26 Böhn L, Störsrud S, Törnblom H, et al. Self-reported food-related gastrointestinal symptoms in IBS are common and associated with more severe symptoms and reduced quality of life. Am J Gastroenterol 2013;108:634-41.

27 Esmaillzadeh A, Hassanzadeh Keshteli A, Hajishafiee M, et al. Consumption of spicy foods and the prevalence of irritable bowel syndrome. World J Gastroenterol 2013:19:6465-71.

28 Akbar A, Yiangou Y, Facer $P$, et al. Increased capsaicin receptor TRPV1-expressing sensory fibres in irritable bowel syndrome and their correlation with abdominal pain. Gut 2008;57:923-9.

29 Tahara T, Shibata T, Nakamura M, et al. Homozygous TRPV1 315C influences the susceptibility to functional dyspepsia. J Clin Gastroenterol 2010;44:e1-7.

30 van Wanrooij SJ, Wouters MM, Van Oudenhove L, et al. Sensitivity testing in irritable bowel syndrome with rectal capsaicin stimulations: role of TRPV1 upregulation and sensitization in visceral hypersensitivity? Am J Gastroentero/ 2014;109:99-109.

31 Lee JH, Lee YS, Lee EJ, et al. Capsiate inhibits DNFB-induced atopic dermatitis in $\mathrm{NC/Nga}$ mice through mast cell and CD4+ T cell inactivation. J Invest Dermatol 2015 Mar 25. Published Online First.

32 Bortolotti M, Porta S. Effect of red pepper on symptoms of irritable bowel syndrome: preliminary study. Dig Dis Sci 2011;56:3288-95.

33 Futagami S, Itoh T, Sakamoto C. Systematic review with meta-analysis: post-infectious functional dyspepsia. Aliment Pharmacol Ther 2015;41:177-88.

34 Schoepfer AM, Schaffer T, Seibold-Schmid B, et al. Antibodies to flagellin indicate reactivity to bacterial antigens in IBS patients. Neurogastroenterol Motil 2008;20:1110-18.

35 Vicario M, González-Castro AM, Martinez C, et al. Increased humoral immunity in the jejunum of diarrhoea-predominant irritable bowel syndrome associated with clinical manifestations. Gut 2014 Sep 10. Published Online First. http://dx.doi.org/ 10.1136/gutjnl-2013-306236

36 Santos J, Benjamin M, Yang PC, et al. Chronic stress impairs rat growth and jejunal epithelial barrier function: role of mast cells. Am J Physiol Gastrointest Liver Physiol 2000;278:G847-854.

37 Vicario M, Guilarte M, Alonso C, et al. Chronological assessment of mast cell-mediated gut dysfunction and mucosal inflammation in a rat model of chronic psychosocial stress. Brain Behav Immun 2010;24:1166-75.

38 van den Wijngaard RM, Stanisor OI, van Diest SA, et al. Peripheral alpha-helical CRF (9-41) does not reverse stress-induced mast cell dependent visceral hypersensitivity in maternally separated rats. Neurogastroenterol Motil 2012;24:274-82, e111.

39 Santos J, Saperas E, Nogueiras C, et al. Release of mast cell mediators into the jejunum by cold pain stress in humans. Gastroenterology 1998;114:640-8.

40 Alonso C, Guilarte M, Vicario M, et al. Acute experimental stress evokes a differential gender-determined increase in human intestinal macromolecular permeability. Neurogastroenterol Motil 2012;24:740-6, e348-349.

41 Wallon C, Yang PC, Keita AV, et al. Corticotropin-releasing hormone (CRH) regulates macromolecular permeability via mast cells in normal human colonic biopsies in vitro. Gut 2008;57:50-8.

42 Vanuytsel T, Van WS, Vanheel $H$, et al. Psychological stress and corticotropin-releasing hormone increase intestinal permeability in humans by a mast cell-dependent mechanism. Gut 2014;63:1293-9.

43 Zheng PY, Feng BS, Oluwole C, et al. Eosinophil-derived corticotrophin releasing hormone links impact of psychological stress to gut epithelial barrier dysfunction. Gut 2009;58:1473-9.

44 Wang L, Stanisz AM, Wershil BK, et al. Substance P induces ion secretion in mouse small intestine through effects on enteric nerves and mast cells. $A m \mathrm{~J}$ Physiol 1995;269:85-92.

45 Barreau F, Cartier C, Ferrier L, et al. Nerve growth factor mediates alterations of colonic sensitivity and mucosal barrier induced by neonatal stress in rats. Gastroenterology 2004;127:524-34.

46 Weston AP, Biddle WL, Bhatia PS, et al. Terminal ileal mucosal mast cells in irritable bowel syndrome. Dig Dis Sci 1993;38:1590-5.

47 Ohman L, Simrén M. Pathogenesis of IBS: role of inflammation, immunity and neuroimmune interactions. Nat Rev Gastroenterol Hepatol 2010;7:163-73.

48 Chadwick VS, Chen W, Shu D, et al. Activation of the mucosal immune system in irritable bowel syndrome. Gastroenterology 2002;122:1778-83.

49 Minnei F, Wetzels C, De Hertogh G, et al. Chronic urticaria is associated with mast cell infiltration in the gastroduodenal mucosa. Virchows Arch 2006;448:262-8.

50 O'Sullivan M, Clayton N, Breslin NP, et al. Increased mast cells in the irritable bowel syndrome. Neurogastroenterol Motil 2000;12:449-57.

51 Braak B, Klooker TK, Wouters MM, et al. Mucosal immune cell numbers and visceral sensitivity in patients with irritable bowel syndrome: is there any relationship? Am J Gastroentero/ 2012;107:715-26.

52 Doyle LA, Sepehr GJ, Hamilton MJ, et al. A clinicopathologic study of 24 cases of systemic mastocytosis involving the gastrointestinal tract and assessment of mucosal mast cell density in irritable bowel syndrome and asymptomatic patients. Am J Surg Pathol 2014;38:832-43.

53 Sethi A, Jain D, Roland BC, et al. Performing colonic mast cell counts in patients with chronic diarrhea of unknown etiology has limited diagnostic use. Arch Pathol Lab Med 2015;139:225-32.
54 Schmulson M, Bielsa MV, Carmona-Sánchez R, et al. Microbiota, gastrointestinal infections, low-grade inflammation, and antibiotic therapy in irritable bowel syndrome: an evidence-based review. Rev Gastroenterol Mex 2014;79:96-134.

55 Ortiz-Lucas M, Saz-Peiro P, Sebastian-Domingo JJ. Irritable bowel syndrome immune hypothesis. Part one: the role of lymphocytes and mast cells. Rev Esp Enferm Dig 2010;102:637-47.

56 Jakate S, Demeo M, John R, et al. Mastocytic enterocolitis: increased mucosal mast cells in chronic intractable diarrhea. Arch Pathol Lab Med 2006;130:362-7.

57 Park JH, Rhee PL, Kim HS, et al. Mucosal mast cell counts correlate with visceral hypersensitivity in patients with diarrhea predominant irritable bowel syndrome. J Gastroenterol Hepatol 2006;21(1 Pt 1):71-8.

58 Wang LH, Fang XC, Pan GZ. Bacillary dysentery as a causative factor of irritable bowel syndrome and its pathogenesis. Gut 2004;53:1096-101.

59 Park $\mathrm{CH}$, Joo YE, Choi SK, et al. Activated mast cells infiltrate in close proximity to enteric nerves in diarrhea-predominant irritable bowel syndrome. J Korean Med Sci 2003;18:204-10.

60 Piche T, Saint-Paul MC, Dainese R, et al. Mast cells and cellularity of the colonic mucosa correlated with fatigue and depression in irritable bowel syndrome. Gut 2008;57:468-73.

61 Walker MM, Talley NJ, Prabhakar M, et al. Duodenal mastocytosis, eosinophilia and intraepithelial lymphocytosis as possible disease markers in the irritable bowel syndrome and functional dyspepsia. Aliment Pharmacol Ther 2009;29:765-73.

62 Guilarte M, Santos J, de Torres I, et al. Diarrhoea-predominant IBS patients show mast cell activation and hyperplasia in the jejunum. Gut 2007;56:203-9.

63 Dunlop SP, Jenkins D, Neal KR, et al. Relative importance of enterochromaffin cell hyperplasia, anxiety, and depression in postinfectious IBS. Gastroenterology 2003;125:1651-9.

64 Hall W, Buckley M, Crotty $\mathrm{P}$, et al. Gastric mucosal mast cells are increased in Helicobacter pylori-negative functional dyspepsia. Clin Gastroenterol Hepatol 2003;1:363-9.

65 Yeom JS, Choi MB, Seo JH, et al. Relationship between headache and mucosal mast cells in pediatric Helicobacter pylori-negative functional dyspepsia. Cephalalgia 2013;33:323-9.

66 Wang X, Li X, Ge W, et al. Quantitative evaluation of duodenal eosinophils and mast cells in adult patients with functional dyspepsia. Ann Diagn Pathol 2015;19:50-6.

67 Schurman JV, Singh M, Singh V, et al. Symptoms and subtypes in pediatric functional dyspepsia: relation to mucosal inflammation and psychological functioning. J Pediatr Gastroenterol Nutr 2010;51:298-303.

68 Lee $\mathrm{H}$, Chung $\mathrm{H}$, Park JC, et al. Heterogeneity of mucosal mast cell infiltration in subgroups of patients with esophageal chest pain. Neurogastroenterol Motil 2014;26:786-93.

69 Lee KJ, Kim YB, Kim JH, et al. The alteration of enterochromaffin cell, mast cell, and lamina propria $T$ lymphocyte numbers in irritable bowel syndrome and its relationship with psychological factors. J Gastroenterol Hepatol 2008;23:1689-94.

70 Goral V, Kucukoner M, Buyukbayram H. Mast cells count and serum cytokine levels in patients with irritable bowel syndrome. Hepatogastroenterology 2010;57:751-4.

71 Dunlop SP, Jenkins D, Spiller RC. Distinctive clinical, psychological, and histological features of postinfective irritable bowel syndrome. Am J Gastroenterol 2003;98:1578-83.

72 Bhuiyan MR, Majumder TK, Raihan AA, et al. Histopathological alterations in post-infectious irritable bowel syndrome in Bangladeshi population. Mymensingh Med J 2010;19:275-81.

$73 \mathrm{Kim}$ HS, Lim JH, Park H, et al. Increased immunoendocrine cells in intestinal mucosa of postinfectious irritable bowel syndrome patients 3 years after acute Shigella infection-an observation in a small case control study. Yonsei Med J 2010;51:45-51.

74 Cremon C, Gargano L, Morselli-Labate AM, et al. Mucosal immune activation in irritable bowel syndrome: gender-dependence and association with digestive symptoms. Am J Gastroenterol 2009;104:392-400.

75 Li X, Chen H, Lu H, et al. The study on the role of inflammatory cells and mediators in post-infectious functional dyspepsia. Scand J Gastroenterol 2010;45:573-81.

76 Houghton LA, Lea R, Jackson N, et al. The menstrual cycle affects rectal sensitivity in patients with irritable bowel syndrome but not healthy volunteers. Gut 2002;50:471-4.

77 Dothel G, Barbaro MR, Boudin H, et al. Nerve fiber outgrowth is increased in the intestinal mucosa of patients with irritable bowel syndrome. Gastroenterology 2015;148:1002-11.

78 Barbara G, Wang B, Stanghellini V, et al. Mast cell-dependent excitation of visceral-nociceptive sensory neurons in irritable bowel syndrome. Gastroenterology 2007;132:26-37.

79 Cenac N, Andrews CN, Holzhausen M, et al. Role for protease activity in visceral pain in irritable bowel syndrome. J Clin Invest 2007;117:636-47.

80 Buhner S, Li Q, Vignali S, et al. Activation of human enteric neurons by supernatants of colonic biopsy specimens from patients with irritable bowel syndrome. Gastroenterology 2009;137:1425-34. 
81 Rijnierse $A$, te Velde AA, Pronk I, et al. Clinical relevance of IgLC in Inflammatory Bowel disease and irritable bowel syndrome. In: Neuroimmune regulation of inflammatory responses in inflammatory bowel disease. Wageningen, the Netherlands: Ponsen \& Looijen bv, 113-23, 2006, Chapter 7, Rijnierse A, Doctoral Thesis.

82 Schemann M, Camilleri M. Functions and imaging of mast cell and neural axis of the gut. Gastroenterology 2013;144:698-704.

83 Feng B, La JH, Schwartz ES, et al. Irritable bowel syndrome: methods, mechanisms, and pathophysiology. Neural and neuro-immune mechanisms of visceral hypersensitivity in irritable bowel syndrome. Am J Physiol Gastrointest Liver Physiol 2012;302:G1085-98.

84 Wang GD, Wang XY, Liu S, et al. Innervation of enteric mast cells by primary spinal afferents in guinea pig and human small intestine. Am J Physiol Gastrointest Liver Physiol 2014;307:G719-31.

85 Buhner S, Braak B, Li Q, et al. Neuronal activation by mucosal biopsy supernatants from irritable bowel syndrome patients is linked to visceral sensitivity. Exp Physiol 2014;99:1299-311.

86 Cenac N, Bautzova T, Le Faouder P, et al. Quantification and potential functions of endogenous agonists of transient receptor potential channels in patients with irritable bowel syndrome. Gastroenterology 2015 Apr 22. Published Online First. pii: S0016-5085(15)00567-3.

87 Balestra B, Vicini R, Cremon C, et al. Colonic mucosal mediators from patients with irritable bowel syndrome excite enteric cholinergic motor neurons. Neurogastroenterol Motil 2012;24:1118-e570.

88 Valdez-Morales EE, Overington J, Guerrero-Alba R, et al. Sensitization of peripheral sensory nerves by mediators from colonic biopsies of diarrhea-predominant irritable bowel syndrome patients: a role for PAR2. Am J Gastroenterol 2013;108:1634-43.

89 Santos J, Yang PC, Söderholm JD, et al. Role of mast cells in chronic stress induced colonic epithelial barrier dysfunction in the rat. Gut 2001;48:630-6.

90 Camilleri M, Lasch K, Zhou W. Irritable bowel syndrome: methods, mechanisms, and pathophysiology. The confluence of increased permeability, inflammation, and pain in irritable bowel syndrome. Am J Physiol Gastrointest Liver Physiol 2012;303: G775-85.

91 Martínez C, Vicario M, Ramos L, et al. The jejunum of diarrhea-predominant irritable bowel syndrome shows molecular alterations in the tight junction signaling pathway that are associated with mucosal pathobiology and clinical manifestations. Am J Gastroenterol 2012;107:736-46.

92 Jacob C, Yang PC, Darmoul D, et al. Mast cell tryptase controls paracellular permeability of the intestine. Role of protease-activated receptor 2 and beta-arrestins. J Biol Chem 2005;280:31936-48.

93 Alonso $C$, Vicario $M$, Pigrau $M$, et al. Intestinal barrier function and the brain-gut axis. Adv Exp Med Biol 2014;817:73-113.

94 Groschwitz KR, Ahrens R, Osterfeld H, et al. Mast cells regulate homeostatic intestinal epithelial migration and barrier function by a chymase/Mcpt4-dependent mechanism. Proc Natl Acad Sci USA 2009;106:22381-6.

95 Vivinus-Nébot $M$, Dainese R, Anty R, et al. Combination of allergic factors can worsen diarrheic irritable bowel syndrome: role of barrier defects and mast cells. Am J Gastroenterol 2012;107:75-81.

96 Zhou Q, Zhang B, Verne GN. Intestinal membrane permeability and hypersensitivity in the irritable bowel syndrome. Pain 2009;146:41-6.

97 Bolin TD. Use of oral sodium cromoglycate in persistent diarrhoea. Gut 1980;21:848-50.

98 Akhavein MA, Patel NR, Muniyappa PK, et al. Allergic mastocytic gastroenteritis and colitis: an unexplained etiology in chronic abdominal pain and gastrointestinal dysmotility. Gastroenterol Res Pract 2012;2012:950582.

99 Friesen CA, Sandridge L, Andre L, et al. Mucosal eosinophilia and response to H1/ $\mathrm{H} 2$ antagonist and cromolyn therapy in pediatric dyspepsia. Clin Pediatr (Phila) 2006:45:143-7.

100 Stefanini GF, Saggioro A, Alvisi V, et al. Oral cromolyn sodium in comparison with elimination diet in the irritable bowel syndrome, diarrheic type. Multicenter study of 428 patients. Scand J Gastroenterol 1995;30:535-41.

101 Lunardi C, Bambara LM, Biasi D, et al. Double-blind cross-over trial of oral sodium cromoglycate in patients with irritable bowel syndrome due to food intolerance. Clin Exp Allergy 1991;21:569-72.

102 Leri 0 , Tubili S, De Rosa FG, et al. Management of diarrhoeic type of irritable bowel syndrome with exclusion diet and disodium cromoglycate. Inflammopharmacology 1997;5:153-38.

103 Klooker TK, Braak B, Koopman KE, et al. The mast cell stabiliser ketotifen decreases visceral hypersensitivity and improves intestinal symptoms in patients with irritable bowel syndrome. Gut 2010;59:1213-21.

104 Jones NL, Roifman CM, Griffiths AM, et al. Ketotifen therapy for acute ulcerative colitis in children: a pilot study. Dig Dis Sci 1998;43:609-15.

105 Tremaine WJ, Brzezinski A, Katz JA, et al. Treatment of mildly to moderately active ulcerative colitis with a tryptase inhibitor (APC 2059): an open-label pilot study. Aliment Pharmacol Ther 2002;16:407-13.

106 Lobo B, Pigrau M, Martinez C, et al. Clinical Benefit and Intestinal Mucosal Transcriptome Modulation After Long-Term Mast Cell Stabilization With Oral
Disodium Cromoglycate in Diarrhea-Predominant Irritable Bowel Syndrome (IBS-D) Patients. Gastroenterology 2015;148(Suppl 1):S-494.

107 Horan RF, Sheffer AL, Austen KF. Cromolyn sodium in the management of systemic mastocytosis. J Allergy Clin Immunol 1990;85:852-5.

108 Corinaldesi R, Stanghellini V, Cremon C, et al. Effect of mesalazine on mucosal immune biomarkers in irritable bowel syndrome: a randomized controlled proof-of-concept study. Aliment Pharmacol Ther 2009;30:245-52.

109 Barbara G, Cremon C, Annese V, et al. Randomised controlled trial of mesalazine in IBS. Gut 2014 Dec 22. Published Online First. pii: gutjnl-2014-308188.

110 Lam C, Tan W, Leighton M, et al. A mechanistic multicentre, parallel group, randomised placebo-controlled trial of mesalazine for the treatment of IBS with diarrhoea (IBS-D). Gut 2015 Mar 12. Published Online First.

111 Pardanani A. How I treat patients with indolent and smoldering mastocytosis (rare conditions but difficult to manage. Blood 2013;121:3085-94.

112 Van Wanrooij S, Wouters M, Van Oudenhove L, et al. Effect of the H1-Receptor Antagonist Ebastin on Visceral Perception and Clinical Symptoms in IBS Gastroenterology 2013;114(Suppl 1):S-160.

113 Fichna J, Sałaga M, Stuart J, et al. Selective inhibition of FAAH produces antidiarrheal and antinociceptive effect mediated by endocannabinoids and cannabinoid-like fatty acid amides. Neurogastroenterol Motil 2014;26:470-81.

114 De Filippis D, Negro L, Vaia M, et al. New insights in mast cell modulation by palmitoylethanolamide. CNS Neurol Disord Drug Targets 2013;12:78-83.

115 Park HH, Lee S, Son HY, et al. Flavonoids inhibit histamine release and expression of proinflammatory cytokines in mast cells. Arch Pharm Res 2008:31:1303-11.

116 Li GX, Wang XM, Jiang T, et al. Berberine prevents intestinal mucosal barrier damage during early phase of sepsis in rat through the toll-like receptors signaling pathway. Korean J Physiol Pharmacol 2015;19:1-7.

117 Solà R, Valls RM, Puzo J, et al. Effects of poly-bioactive compounds on lipid profile and body weight in a moderately hypercholesterolemic population with low cardiovascular disease risk: a multicenter randomized trial. PLOS ONE 2014;9: e101978.

118 Russo M, Spagnuolo C, Volpe S, et al. Quercetin induced apoptosis in association with death receptors and fludarabine in cells isolated from chronic lymphocytic leukaemia patients. Br J Cancer 2010;103:642-8.

119 Santos J, Guilarte M, Alonso C, et al. Pathogenesis of irritable bowel syndrome: the mast cell connection. Scand J Gastroenterol 2005;40:129-40.

120 Neilan NA, Garg UC, Schurman JV, et al. Intestinal permeability in children/ adolescents with functional dyspepsia. BMC Res Notes 2014;7:275.

121 Matter SE, Bhatia PS, Miner PB Jr. Evaluation of antral mast cells in nonulcer dyspepsia. Dig Dis Sci 1990;35:1358-63.

122 Di Nardo G, Barbara G, Cucchiara S, et al. Neuroimmune interactions at different intestinal sites are related to abdominal pain symptoms in children with IBS. Neurogastroenterol Motil 2014;26:196-204.

123 Yang J, Fox M, Cong Y, et al. Lactose intolerance in irritable bowel syndrome patients with diarrhoea: the roles of anxiety, activation of the innate mucosal immune system and visceral sensitivity. Aliment Pharmacol Ther 2014;39:302-11.

124 Sohn W, Lee OY, Lee SP, et al. Mast cell number, substance $P$ and vasoactive intestinal peptide in irritable bowel syndrome with diarrhea. Scand J Gastroenterol 2014:49:43-51.

125 Ahn JY, Lee $\mathrm{KH}$, Choi $\mathrm{CH}$, et al. Colonic mucosal immune activity in irritable bowe syndrome: comparison with healthy controls and patients with ulcerative colitis. Dig Dis Sci 2014;59:1001-11.

126 Vivinus-Nébot $M$, Frin-Mathy $G$, Bzioueche $H$, et al. Functional bowel symptoms in quiescent inflammatory bowel diseases: role of epithelial barrier disruption and low-grade inflammation. Gut 2014;63:744-52.

127 Lee $\mathrm{H}$, Park JH, Park DI, et al. Mucosal mast cell count is associated with intestinal permeability in patients with diarrhea predominant irritable bowel syndrome. J Neurogastroenterol Motil 2013;19:244-50.

128 Kerckhoffs AP, ter Linde JJ, Akkermans LM, et al. SERT and TPH-1 mRNA expression are reduced in irritable bowel syndrome patients regardless of visceral sensitivity state in large intestine. Am J Physiol Gastrointest Liver Physiol 2012;302: G1053-60.

129 Willot S, Gauthier C, Patey N, et al. Nerve growth factor content is increased in the rectal mucosa of children with diarrhea-predominant irritable bowel syndrome. Neurogastroenterol Motil 2012;24:734-9, e347.

130 Cremon C, Carini G, Wang B, et al. Intestinal serotonin release, sensory neuron activation, and abdominal pain in irritable bowel syndrome. Am J Gastroenterol 2011;106:1290-8.

131 Coëffier M, Gloro R, Boukhettala N, et al. Increased proteasome-mediated degradation of occludin in irritable bowel syndrome. Am J Gastroenterol 2010;105:1181-8.

132 Wang SH, Dong L, Luo JY, et al. Decreased expression of serotonin in the jejunum and increased numbers of mast cells in the terminal ileum in patients with irritable bowel syndrome. World J Gastroenterol 2007;13:6041-7.

133 Törnblom H, Lindberg G, Nyberg B, et al. Full-thickness biopsy of the jejunum reveals inflammation and enteric neuropathy in irritable bowel syndrome. Gastroenterology 2002;123:1972-9. 


\section{Recent advances in basic science}

134 Spiller RC, Jenkins D, Thornley JP, et al. Increased rectal mucosal enteroendocrine cells, T lymphocytes, and increased gut permeability following acute Campylobacter enteritis and in post-dysenteric irritable bowel syndrome. Gut 2000;47:804-11.

135 Marsh MN, Hinde J. Inflammatory component of celiac sprue mucosa. I. Mast cells, basophils, and eosinophils. Gastroenterology 1985;89:92-101.

$136 \mathrm{He} \mathrm{SH}$. Key role of mast cells and their major secretory products in inflammatory bowel disease. World J Gastroenterol 2004;10:309-18.

137 Bassotti G, Villanacci V, Nascimbeni R, et al. The role of colonic mast cells and myenteric plexitis in patients with diverticular disease. Int J Colorectal Dis 2013;28:267-72.
138 Feldman M, Friedman L, Brandt L, eds. Gastrointestinal and liver disease. 8th edn. Philadelphia, PA: Saunders, 2006:31.

139 Wilcz-Villega EM, McClean S, O'Sullivan MA. Mast cell tryptase reduces junctional adhesion molecule-A (JAM-A) expression in intestinal epithelial cells: implications for the mechanisms of barrier dysfunction in irritable bowel syndrome. Am J Gastroenterol 2013;108:1140-51.

140 Burleigh D, Fernandes K, Perrett D. T(84) epithelial cells respond to 5 -hydroxytryptamine when grown in serum-free media. Eur J Pharmacol 2000;390:103-6. 